\title{
DEMOCRATIZING THE ECONOMIC SPHERE: A CASE FOR THE POLITICAL BOYCOTT
}

\author{
Theresa J. Lee
}

The political boycott, though recently under attack through litigation aimed at compelled disclosure regimes, is a critical tool in constructing American democracy. Defining political boycotts as those refusals by consumers to buy goods or patronize business in order to effect political or social change, this Article is the first paper to place the political boycott at home in all three classic theories underlying the First Amendment: the marketplace of ideas, democracy and self-governance, and self-expression and autonomy. It also places the boycott alongside current campaign finance doctrine via Citizens United v. FEC. Just as money amassed by corporations in the economic marketplace can be used to influence the political, the boycott allows those whose main economic resource is their participation in the market as consumers to aggregate that resource, with other like-minded consumers, to influence the political marketplace.

The paper also explores the doctrinal implications of these arguments for ongoing lawsuits challenging compelled disclosure regimes. As-applied challenges to such laws can be granted upon a sufficient evidentiary showing of "threats, harassment, or reprisals." This Article argues that the boycott cannot be categorized in this way. Especially in the case of initiatives and referenda, the political boycott is a critical tool of petition and should not be considered in this as-applied harassment analysis.

\section{TABLE OF CONTENTS}

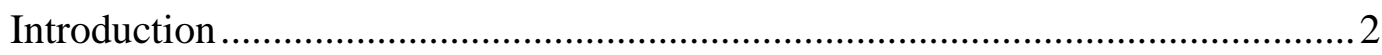

I. The Political Boycott ......................................................................................... 8

A. A Brief History of the Political Boycott in the United States.......................8

B. The Political Boycott in the Courts ............................................................... 14

II. The Political Boycott and Theories of the First Amendment..............................17

A. Marketplace of Ideas .............................................................................. 17

B. Democracy / Self-Governance .....................................................................22

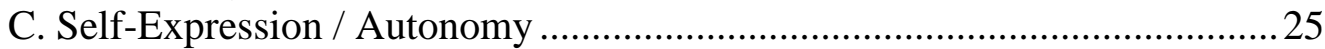

III. Boycotts and Compelled Disclosure Doctrine ...............................................22

A. Exemptions from Compelled Disclosure ....................................................2 27

B. Government Interest in Compelled Disclosure in the Case of Initiatives and Referenda and the Need for the Boycott............................29

\footnotetext{
* Associate Research Scholar in Law, San Francisco Affirmative Litigation Project Fellow, and Lecturer in Law, Yale Law School. J.D. 2011, Yale. I would like to thank Heather Gerken, Robert Post, Doug Kysar, Anjali Dalal, Arpit Garg, and Aaron Zelinsky for their extraordinarily helpful comments and critiques. All mistakes are, of course, my own.
} 
IV. A Response to Administrability Concerns............................................................34

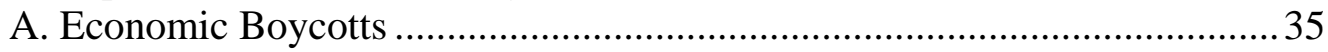

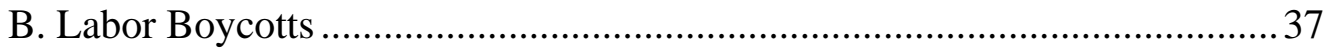

C. Difference Between Individual Economic Retaliation and Boycotts...........38

D. Concern Over "Less Legitimate” Boycotts..................................................... 40

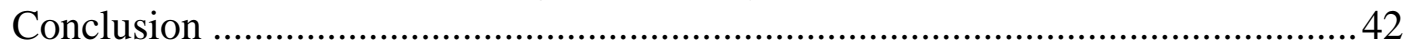

INTRODUCTION

Following the passage of Proposition 8 in California, the director of the Prop. 8 campaign, bemoaning the compelled disclosure of campaign donors, declared that protestors "don't have a right to blacklist and boycott our supporters." "While such rhetoric is run of the mill, when such claims spill out of the court of public opinion and into the actual courts, a key First Amendment right is put at risk. Following a decades-long assault on campaign finance more broadly, the past three years have seen a turn against disclosure, the one tool that was once widely lauded on all sides of the debate. ${ }^{2}$ This generation of disclosure challenges ${ }^{3}$ are characterized by efforts to paint a narrative of "threats, harassment, or reprisals"4 in order to obtain an as-applied exemption from these laws of general applicability. Common to all of these claims is the inclusion of the boycott in the litany of dangers some believe political supporters face. ${ }^{5}$ While boycotts may draw the ire of those targeted, it is exactly because they are felt that they are not ignored and instead portrayed as something other than what they are: protected First Amendment activity. Boycotts have long been a subject of contention, but in the case of political boycotts, they have also played a

\footnotetext{
${ }^{1}$ Martin Wisckol, Prop. 8 Leaders Accuse Foes of Harassment, Intimidation, ORANGE COUNTY REGISTER, Nov. 15, 2008.

${ }^{2}$ See, e.g., Richard L. Hasen, Chill Out: A Qualified Defense of Campaign Finance Disclosure Laws in the Internet Age, 27 J.L. \& PoL. (forthcoming 2012).

${ }^{3}$ See, e.g., ProtectMarriage.com v. Bowen, -- F. Supp. 2d --, 2011 WL 5507204 (E.D. Cal. Nov. 4, 2011); Doe v. Reed, -- F. Supp. 2d --, 2011 WL 5403218 (W.D. Wash. Nov. 8, 2011); Nat'l Org. for Marriage v. McKee, 649 F.3d 34 (1st Cir. 2011); Citizens United v. Fed. Election Comm'n, 130 S. Ct. 876 (2010).

${ }^{4}$ Buckley v. Valeo, 424 U.S. 1, 74 (1976).

${ }^{5}$ See, e.g., Protectmarriage.com v. Bowen, 599 F. Supp. 2d 1197, 1201 (E.D. Cal. 2009) (quoting Declaration of John Doe \#1) ("His business has since been targeted by numerous boycotts, several orchestrated through Facebook. At one point, someone paid for a sponsored link on Google so that a search for John Doe \#1's store resulted in a website referencing his support for Proposition 8 and urging a boycott."); Doe v. Reed, No. 09-559, Pet. Br. 11 ("Boycotts were threatened: 'We shall boycott the businesses of EVERYONE who signs your odious, bigoted petition.'”); Citizens United v. Fed. Election Comm'n, 130 S. Ct. 876, 981 (2010) (Thomas, J., concurring in part, dissenting in part) ("opponents threatened to boycott and picket the next festival”).
} 
critical role in American democracy. ${ }^{6}$ This Article considers the status of the political consumer boycott, defined as a refusal to buy goods or patronize certain business undertaken by individuals in their role as consumers and citizens in order to effect political or social change. It challenges the recent effort to recharacterize the political boycott. It is the first Article to situate the political boycott within all three classic theories underlying the First Amendment, showing not only the historical and precedential underpinnings of the boycott, but arguing that this type of political activity lives up to the values that motivate constitutional protection. Not only is the boycott a mode of political action of long pedigree, ${ }^{7}$ it is a particularly well-suited tool of political action and agency creation in a political landscape dominated by interests related not to voting power but to monetary power. ${ }^{8}$ In a time with the highest levels of campaign contribution and spending in history, ${ }^{9}$ the boycott is not some antiquated last ditch resort, but rather the manifestation of money as speech for those without extreme wealth-power accumulated in the economic marketplace-coming to bear on the political sphere.

Boycotts are indeed powerful. They do, in fact, have the ability to exact real-world, human costs from those businesses and individuals who are targeted by a boycott. The concern over boycotts exists because they have consequences that might have the potential to even extend outward from their target to impact a boycotted business's employees or community. Recognizing this impact, however, does not conclude the analysis. The profound First Amendment benefits of the boycott, in terms of the core political speech so implicated, the ability of the boycott to place consumers, usually the lowliest player in the economic sphere on more equal footing with producers when it comes to impacting the political sphere, and the invaluable information disclosure regimes bestow on the entire electorate and the State outweigh the possible day-to-day impacts of the boycott.

Boycotts are often invoked as an unfortunate collateral consequence that comes with efforts towards accountability and transparency. This is a mistake. The boycott is formative to the project of American democracy

\footnotetext{
${ }^{6}$ See generally Lawrence B. Glickman, Buying Power: A History of Consumer ACTIVISM IN AMERICA (2009) (presenting history of consumer boycotts in America as political activity).

${ }^{7}$ See generally GARY MiNDA, BOYCOTT IN AMERICA (1999).

8 See, e.g., Ciara Torres-Spelliscy, Brennan Ctr. for Justice, Corporate CAMPAign Spending: Giving Shareholders A Voice 5-10 (2010) (considering the impact of Citizens United).

${ }^{9}$ Eduardo Porter, How the Big Money Finds a Way In, N.Y. Times, Sept. 18, 2011 ("Soaring Federal Election Spending" Graph), available at http://www.nytimes.com/imagepages/2011/09/18/opinion/sunday/18editorial_deconstructio n1.html?ref=sunday.
} 
and vindicates key First Amendment values. It should be celebrated, not mourned. In addition to this theoretical claim, the Article also presents a related doctrinal charge: the boycott cannot legitimately be used to undermine compelled disclosure regimes. Compelled disclosure regimes have consistently been upheld by the courts, but as consistently, the courts have recognized that in a particular instance, a group could prevail in an asapplied challenge to compelled disclosure due to "threats, harassment, or reprisals."10 Political boycotts are expressly acknowledged in compelled disclosure litigation as an unfortunate, negative consequence or, at best, merely ancillary to the informational and accountability benefits of the disclosure regime. $^{11}$ For example, in a challenge to California's Political Reform Act, ${ }^{12}$ the district court, while nonetheless finding in favor of disclosure, underscores the importance of the state's informational interest in disclosure as wholly distinct from any individual's additional use of public information to facilitate a boycott. ${ }^{13}$

This long-accepted form of political engagement blends economic and expressive elements. Some may have the instinct to recoil from the boycott for this very reason, trying to wall off the political from the economic. To dismiss the boycott on these grounds is misguided, as the political and the economic are already constantly thrust against one another, and the political boycott serves as a critical counterweight to the intersection between these two spheres elsewhere. In today's current climate, where the political and economic spheres are so tightly intertwined $^{14}$ and democratic activity has long since bubbled outside of organized campaigns and the voting booth, ${ }^{15}$ the boycott should be viewed

${ }^{10}$ Brown v. Socialist Workers '74 Campaign Comm., 459 U.S. 87, 100 (1982); Buckley v. Valeo, 424 U.S. 1, 74 (1976).

${ }^{11}$ See, e.g., ProtectMarriage.com v. Bowen, 599 F. Supp. 2d 1197, 1219 (E.D. Cal. 2009).

${ }^{12}$ ProtectMarriage.com v. Bowen, -- F. Supp. 2d --, 2011 WL 5507204 (E.D. Cal. Nov. 4, 2011).

${ }^{13}$ ProtectMarriage.com, 599 F. Supp. 2d at 1219.

${ }^{14}$ Susan M. Liss \& Michael Waldman, Brennan Ctr. For Justice, Renewing DEMOCRACY AFTER CITIZENS UNITED 2 (2010) (identifying politics as "money drenched;" highlighting big money lobbying efforts); Citizens United v. Fed. Election Comm'n, 130 S. Ct. 876, 913 (2010)(overruling Austin v. Michigan Chamber of Commerce, 494 U.S. 652, 659 (1990), which prevented corporate spending because the status of corporations allowed 'them to use 'resources amassed in the economic marketplace' to obtain 'an unfair advantage in the political marketplace.”')

${ }^{15}$ Michael Hardt \& Antonio Negri, The Fight for "Real Democracy" at the Heart of Occupy Wall Street, ForEIGN AFF. (Oct. 11. 2011), http://www.foreignaffairs.com/ print/98542?page=show (presenting the Occupy Wall Street protests as a reaction to lack of real political representation); Jeremy Kessler, Occupy Wall Street and the Rediscovery of Politics, THE UtOPIAN (Dec. 5, 2011), http://www.the-utopian.org/post/13785153936/ occupy-wall-street-and-the-rediscovery-of-politics (looking at Occupy Wall Street as 
with the highest respect. Thus, this Article recognizes the political boycott not only as a long-established and distinguished form of political expression in the United States, but also as particularly fitting in the current clime. Three distinct strands characterize the current American political moment: (1) many people do not believe that they are represented by their elected leaders; ${ }^{16}$ (2) there is an unprecedented amount of money pouring into elections and lobbying of elected officials; ${ }^{17}$ and (3) much democratic activity is taking place outside of the ballot box as the economic crisis causes people to reassess their political abilities. ${ }^{18}$ This third factor can perhaps be seen as a positive response to these first two concerns.

Rather than being an example of threats or harassment, the political boycott is wholly consistent when viewed through the lenses of history, precedent, and the theories of the First Amendment. And while the concern over the boycott is neither a singular nor a new phenomenon, ${ }^{19}$ the current complaints regarding political boycotts are more than mere appeals by those boycotted for public support. Such complaints are being deployed in litigation $^{20}$ in order to challenge the campaign finance and other public disclosure regimes at the heart of democratic accountability and transparency. $^{21}$ The Supreme Court has consistently upheld compelled disclosure regimes, leaving the door open for as-applied exemptions. ${ }^{22}$ The protected status of the boycott under the First Amendment cautions very strongly against using it as evidence of the "threats, harassment, or

political activity "beyond the prescribed avenues of official political reform”).

${ }^{16}$ Hardt \& Negri, supra note 15.

${ }^{17}$ See, e.g., Brad Knickerbocker, Behind the Meteoric Rise in Campaign Spending, Christian SCI. Monitor, Nov. 14, 2010, http://www.csmonitor.com/USA/Politics/TheVote/2010/1114/Behind-the-meteoric-rise-in-campaign-spending.

${ }^{18}$ Hardt \& Negri, supra note 15.

${ }^{19}$ GLICKMAN, supra note 6, at 133-151.

${ }^{20}$ See Protectmarriage.com v. Bowen, 599 F. Supp. 2d 1197, 1201 (E.D. Cal. 2009) (quoting Declaration of John Doe \#1) ("His business has since been targeted by numerous boycotts, several orchestrated through Facebook. At one point, someone paid for a sponsored link on Google so that a search for John Doe \#1's store resulted in a website referencing his support for Proposition 8 and urging a boycott."); Doe v. Reed, No. 09-559, Pet. Br. 11 ("Boycotts were threatened: 'We shall boycott the businesses of EVERYONE who signs your odious, bigoted petition.'”); Citizens United v. Fed. Election Comm'n, 130 S. Ct. 876, 981 (2010) (Thomas, J., concurring in part, dissenting in part) ("opponents threatened to boycott and picket the next festival").

${ }^{21}$ See, e.g., ProtectMarriage.com v. Bowen, -- F. Supp. 2d --, 2011 WL 5507204 (E.D. Cal. Nov. 4, 2011); Doe v. Reed, -- F. Supp. 2d --, 2011 WL 5403218 (W.D. Wash. Nov. 8, 2011); Nat'l Org. for Marriage v. McKee, 649 F.3d 34 (1st Cir. 2011); Citizens United v. Fed. Election Comm'n, 130 S. Ct. 876 (2010).

${ }^{22}$ Buckley v. Valeo, 424 U.S. 1, 69-74 (1976); McConnell v. FEC, 540 U.S. 93, 194202 (2003); Citizens United v. FEC, 130 S. Ct. 876, 913-916 (2010). 
reprisals" ${ }^{23}$ that necessitate an as-applied exemption. This Article argues that the boycott should not be considered in harassment analysis in cases of compelled disclosure.

This Article establishes the historical and legal development of the political boycott in the United States. Beginning by sketching out the historical trajectory of boycotts from the colonial era through the modern day, Part I presents the boycott as used by various groups, showing its role as one of the most valued forms of protest in the United States. Part I moves on to trace the path of the political boycott in the federal courts. Strong precedent recognizes the value of the boycott and cautions against conceiving of the boycott in these same courts as something other than protected activity. This Part emphasizes the roots of the boycott in democracy formation in the United States as to turn the eye toward the modern boycott with a clear understanding of the importance of this form of political activity.

In Part II, this Article then proceeds to situate the boycott in the three classic theories of the First Amendment: (1) the marketplace of ideas; (2) democracy and self-governance; and (3) self-expression and autonomy. The political boycott serves the value of the marketplace of ideas in a twofold way. First, the boycott serves to push ideas into the marketplace to be tested for their value. Boycotts are classic examples of the marketplace of ideas as they, more than other forms of political conduct, necessarily depend on convincing others for their very continuation. Second, political boycotts are an instantiation of the marketplace of ideas. Ideas and the actual market interact in order to press for political change.

The mingling of the economic and the political may give pause to some, but the boycott is a needed counterweight to the other varied examples of the political and economic spheres mixing in American society. There is a highly-regulated area of law where these two spheres already mix: campaign finance. This Article applies recent campaign finance theory and doctrine to the political boycott to show the impossibility of setting the boycott outside the protections of the First Amendment.

Part II moves on to situate the boycott as an exercise in democracy and self-governance. Under the First Amendment self-governance theories of both Alexander Meiklejohn ${ }^{24}$ and Robert Post, ${ }^{25}$ the political boycott passes muster. Boycotts are information-forcing; they provide what people need in order to make informed decisions in a democracy, as Meiklejohn

${ }^{23}$ Brown v. Socialist Workers ‘74 Campaign Comm., 459 U.S. 87, 100 (1982).

${ }^{24}$ Alexander Meiklejohn, Free SPeEch and its Relation to Self-Government (1948).

${ }^{25}$ Robert Post, Reconciling Theory and Doctrine in First Amendment Jurisprudence, 88 CALIF. L. REV. 2353, 2367 (2000). 
requires. They are also classically participatory, serving as a process by which individuals identify with their political system and government, thus illustrating Post's theory of self-governance as well.

The final theory of the First Amendment, self-expression and autonomy gels with the political boycott as every boycott exists through "a host of voluntary decisions by free citizens." 26 When considered through the lens of this theory, there is value even in an unsuccessful boycott. While no other minds may be changed in the end, an unsuccessful boycott still provides internal effectiveness to those participating, allowing them to construct their own selves through their market choices.

Part III next moves from the theoretical to the doctrinal. Presenting compelled disclosure regimes, this Part considers the as-applied standard for challenges against such laws and argues that boycotts can never rightly be considered examples of "threats, harassment, or reprisals," 27 as the doctrine requires. Further, in response to arguments that non-candidate elections do not provide the same interests recognized in Buckley v. Valeo ${ }^{28}$ to justify a compelled disclosure regime, this Part argues that, in fact, the informational interest at stake in non-candidate elections is higher than it is in candidate elections. Where citizens are akin to both legislators and lobbyists, disclosure is vital because the usual information-providing cues, such as party affiliation, are not available to voters. It is exactly because ordinary people are serving the legislative function that even great deference be given to the boycott. Without constituent services or offices in the state house, boycotts are the only means of petition of one's fellow citizen-legislators.

Part IV presents possible answers to a series of arguments that may attempt to tie the political boycott to other market activity in an effort to upend support for such boycotts. Economic and labor boycotts can be assessed on different grounds than the political boycott, and acceptance of the political does not automatically grant acceptance of these other types of boycotts. For both of these, the existence of a complex federal regime suggests that different state interests than those implicated by the political boycott have been established. The Article thus leaves them to the side for the scope of this work.

This Part also elucidates the difference between individual economic retaliation and the boycott. On average, the power differentials in the situation of individual economic retaliation are so great that it should be set apart for the political boycott. Additionally, the boycott is discursive while

\footnotetext{
${ }^{26}$ NAACP v. Claiborne Hardware Co., 458 U.S. 886, 888-89 (1982).

${ }^{27}$ Brown v. Socialist Workers '74 Campaign Comm., 459 U.S. 87, 100 (1982); Buckley v. Valeo, 424 U.S. 1, 74 (1976).

${ }^{28} 424$ U.S. 1 (1976).
} 
a political firing has no such element. Boycotts also call for a long series of collective decisions, while economic retaliation is unilateral and occurs only at one point in time, without any ability to fluctuate in strength or effect.

Finally, this part turns to concerns over boycotts that are deployed because of who someone is rather than for a clear decisional goal. While Professor Michael Harper has attempted to make a distinction between the First Amendment protections to be afforded to each of these types of boycotts, ${ }^{29}$ his argument is incomplete. The Court has often cautioned against line drawing between closely related identity and conduct. ${ }^{30}$ Trying to pull these two apart is likely a futile effort, and the response to a boycott one considers abhorrent should not be withdrawal of constitutional status but marshaling support for the intended target and using expression in order to shame that boycott into collapsing. The First Amendment is a roughand-tumble place, and a consistent theory of the First Amendment, broadly, and of boycotts, specifically, cannot only grant protection to those actions one sees as laudable.

\section{The Political BoycotT}

\section{A. A Brief History of the Political Boycott in the United States}

The use of the boycott to achieve political ends is older than the United States and was a critical form of political action that gave rise to our colonial revolutionary moment. The deep roots of the political boycott caution its dismissal as mere coercion or inappropriate action. In NAACP v. Claiborne Hardware, ${ }^{31}$ the case where the Supreme Court finally recognized the protected status of the boycott, the NAACP understood the roots of the American political boycott and called on just this long history to underscore the validity of these civil rights boycotters. In oral arguments, Lloyd Cutler grounded his legal argument in the fact "that this nation was born out of a series of colonial boycotts against British merchants in support of petitions to the British king and Parliament for the redress of grievances."32 The use of the boycott did not end with the end of the colonial period and the birth of the nation. In fact, at the time of ratification of the Constitution, founders Alexander Hamilton and John Jay were

29 Michael C. Harper, The Consumer's Emerging Right to Boycott: NAACP v. Claiborne Hardware and Its Implications for American Labor Law, 93 YALE L.J. 409, 42930 (1984).

${ }^{30}$ See, e.g., Buckley v. Valeo, 424 U.S. 1, 66 (1976); Lawrence v. Texas, 539 U.S. 558, 575 (2003).

${ }^{31} 458$ U.S. 886 (1982).

${ }^{32}$ NAACP v. Claiborne Hardware, No. 81-202, Petitioner’s Oral Argument, 5. 
leading a boycott against New York merchants who engaged in the slave trade. $^{33}$ Thus, the boycott is not a tool whose legitimacy must stand apart from the underlying structure of our governance and legal system; it is part and parcel of our system. The boycott is a means of communication, valued under the First Amendment, which has been used on all sides of controversies throughout American history.

As early as 1900 and throughout more than the first half of the twentieth century, boycotts were deployed to fight racial injustice. Between 1900 and 1906, streetcar boycotts took place in over twenty-five Southern cities to fight against the segregation laws of Jim Crow. "Although technically the new segregation laws represented an abridgment of the consumer right to choose . . . symbolically they represented much moreunjust acts whose effect was "to humiliate, to degrade, and to stigmatize."34 These boycotts were largely fueled by cooperation, but in some instances social pressures were used as well, for example, "[i]n Savannah, [Georgia] those who opposed the boycotts were publicly denounced at mass meetings as 'demagogues and hypocrites.",35 The bus boycotts of the 1950s were similar to the streetcar boycotts of the early part of the century; in both instances, the social ill being protested existed within target of the protestsegregated streetcars and buses.

The Montgomery bus boycott-perhaps the "best known and most influential consumer boycott in America's history"36 - continued on strong for more than a year. While the boycott alone did not achieve the social change for which the boycotters aimed, the boycott "along with favorable court decisions, helped to advance the collective interest of the AfricanAmerican community in Montgomery, Alabama."37 In Brower v. Gayle, the Supreme Court affirmed the lower court decision that struck down the state and local laws segregating the busing system. ${ }^{38}$ While it is true that "authorities remained impervious to the adverse publicity the boycott brought them, to the economic losses it caused local business, and to the moral pressures of nonviolent resistance,"39 the federal courts do not operate in a vacuum, and the nationwide focus on this boycott was certainly not missed by the judges of the district court or the Supreme Court justices. ${ }^{40}$ The boycott itself provided social cohesion, ${ }^{41}$ especially between

${ }^{33} I d$. at 8.

${ }^{34}$ Monroe Friedman, Consumer Boycotts 92 (1999).

${ }^{35} \mathrm{Id}$. at 93.

${ }^{36}$ Id. at $96-97$.

${ }^{37}$ MindA, supra note 7, at 134.

38352 U.S. 903 (1956).

39 Catherine A. Barnes, Journey From Jim Crow: The Desegregation of SOUTHERN TRANSIT 124 (1983).

${ }^{40}$ FRIEDMAN, supra note 34 at 104-05. 
classes of African Americans, ${ }^{42}$ and "imbued Dr. King and his organization with a sense of solidarity to implement social change." 43

The civil rights movement used boycotts throughout the South, and unlike those of the Montgomery bus system, the desired social change was not only one that could be granted by the express targets of the boycott. In 1971, the black community staged a boycott of all the white retail merchants in Marianna, Arkansas. The aim of the boycott was to "secure the attention of the 'white establishment'" responsible for many acts of discrimination toward the black residents of Marianna. ${ }^{44}$ After nearly eight months of boycotting, the boycotters submitted a list of demands and both sides requested assistance from a gubernatorial task force. ${ }^{45}$ After the boycott had been in effect for over a year, black leaders cited several areas where progress had been made and the boycott came to an end. The use of economic pressure led to political change.

A similar boycott to that of Marianna gave birth to the Supreme Court jurisprudence recognizing the political boycott as a First Amendment protected form of political speech. Beginning in March of 1966, the black community in Claiborne County, Mississippi, presented white elected officials with a list of demands focused on racial equality and integration, the complaints were brushed aside, and at a local NAACP meeting, a large portion of the black community voted to begin a boycott. ${ }^{46}$ The boycott lasted seven years, calling for "the desegregation of all public schools and public facilities, the hiring of black policemen, public improvements in black residential areas, selection of blacks for jury duty, integration of bus stations so that blacks could use all facilities, and an end to verbal abuse by

41 Randall Kennedy, Martin Luther King's Constitution: A Legal History of the Montgomery Bus Boycott, 98 YALE L.J. 999, 1066 (1989). “The boycott made black Montgomerians aware of themselves as a community with obligations and capacities to which they and others had previously been blind. On the eve of the boycott, few would have imagined the latent abilities that resided within that community. The protest elicited and clarified those abilities. On the eve of the boycott, few black Montgomerians would have considered themselves as persons with important political duties. The protest inculcated and enlarged their sense of responsibility. Moreover, by publicizing their willingness and ability to mobilize united opposition to Jim Crow practices, the protesters in Montgomery contributed a therapeutic dose of inspiration to dissidents everywhere. Later developments would attest to the influence of the boycott as a role model that encouraged other acts of rebellion. Participants in subsequent protests remember Montgomery as a distinct, encouraging presence.”

${ }^{42} I d$. at 1023.

${ }^{43}$ MindA, supra note 7.

${ }^{44}$ FRIEDMAN, supra note 34, at 119.

${ }^{45}$ Id. at 120.

${ }^{46}$ NAACP v. Claiborne Hardware Co., 458 U.S. 886, 889 (1982). 
law enforcement officers." ${ }^{\text {" } 77}$ The petition also asserted "'Negroes are not to be addressed by terms as 'boy,' 'girl,' 'shine,' 'uncle,' or any other offensive term, but as 'Mr.,' 'Mrs.,' or 'Miss,' as is the case with other citizens." ${ }^{48}$ The purpose of the boycott "was to gain equal rights and opportunities for Negro citizens." would not be known until sixteen years after it began. The next section of this Part turns to the substance of the court decision. African-Americans were not the only minority group that has deployed the political boycott in the face of overwhelming social and political forces that could not otherwise be addressed. Both women and gay rights groups have followed in the footsteps of the original civil rights movement using the boycott as a tool to create "solidarity and collective impetus" 50 in order to effect social change. The National Organization of Women deployed boycotts as a means of petitioning state governments in order to try and secure passage of the Equal Rights Amendment. ${ }^{51}$ NOW called upon all supporters of the ERA to refuse to travel to the targeted states and to patronize business therein, and to cancel conferences planned in them. In Missouri, this boycott was challenged by the state as a violation of state tort law and the Sherman Anti-Trust Act. ${ }^{52}$

Gay rights groups have also made use of the boycott. In the early 1990s, the AIDS Coalition to Unleash Power (ACT UP) boycotted Philip Morris in an effort to influence their support of Senator Jesse Helms, who frequently publicly condemned homosexuality. ${ }^{53}$ The boycott failed to dramatically influence support for Helms, but succeeded in bringing gay issues to the consciousness of Philip Morris, which then pledged contributions of more than $\$ 2$ million annually to gay rights and AIDS organizations. $^{54}$ A gay rights boycott of Cracker Barrel began in 1991 following the firing of a number of gay and lesbian employees and the issuance of a statement saying that Cracker Barrel would not hire anyone "whose sexual preferences fail to demonstrate normal, heterosexual values." restaurants, often timed to coincide with the brunch crowds on Sundays, and "slow-down sit-ins" whereby protestors would go into the restaurant and

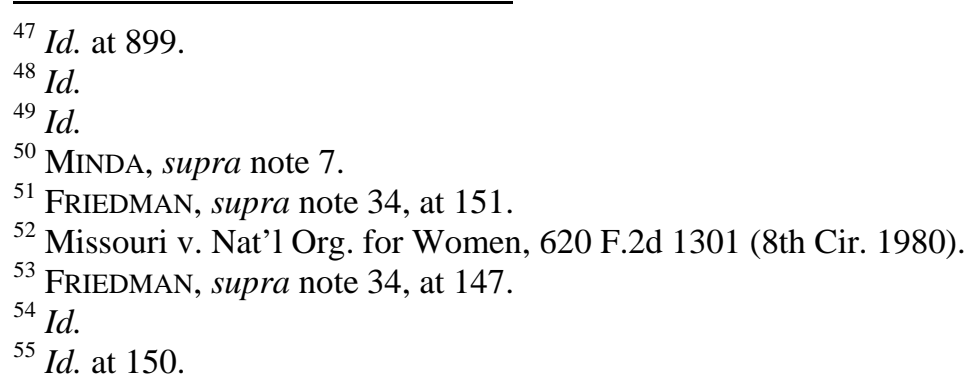


occupy tables for hours while ordering a mere cup of coffee. ${ }^{56}$ This boycott lasted for over a decade, with Cracker Barrel obstinately refusing to consider enacting a non-discrimination policy that protected based on sexual orientation with boycotters, likewise, continuing in their resolve. Over eleven years later, the boycott ended when, in November 2002, the board voted unanimously to enact the non-discrimination policy that had been approved by a $58 \%$ shareholder proxy vote. ${ }^{57}$

A final example of the use of the boycott by gay rights groups parallels the Montgomery Bus Boycott in that the courts ended up undoing "the offensive action that a boycott had attempted to defy." ${ }^{2}$ In 1992, voters in Colorado approved an amendment to the state constitution that would repeal laws preventing discrimination based on sexual orientation and prohibit their passage in the future. ${ }^{59}$ The call for the boycott was made the very next day. The two courses of action for the boycott were to discourage travel to Colorado and to encourage customers not to purchase goods from Colorado businesses. ${ }^{60}$ This boycott was both swift and widespread, with over 100 official participant groups. The impact was being felt in Colorado, but the boycott was suspended in 1994 when the state Supreme Court found the amendment to be unconstitutional. ${ }^{61}$ The United States Supreme Court later went on to affirm the decision of the state court. $^{62}$

The Civil Rights Movement was by no means the only group early

${ }^{56}$ Id.

${ }^{57}$ Jeremy Quittner, Cracker Barrel Buckles: The Family Restaurant's Change of Heart Provides a Prime Example for Activists Committed to Reforming Other Antigay Corporations, THE ADVOCATE, Feb. 4, 2003. ("The change stems in large part from the work of the New York City Employees' Retirement System, one of five pension funds for New York City workers, which together control 391,000 shares of stock in CBRL. . . For 10 years NYCERS has sponsored shareholder proposals that would push Cracker Barrel to overhaul its employment policy through a proxy vote. . . . Prior to the November 26 meeting, shareholders controlling 58\% of CBRL's 49.8 million outstanding shares voted by proxy to approve the proposal. Although no vote was formally taken at the meeting, immediately afterward the board voted unanimously to adopt the nondiscrimination policy.”)

${ }^{58}$ FRIEDMAN, supra note 34, at 149.

${ }^{59}$ The text of Amendment 2 read: "Neither the state of Colorado, through any of its branches or departments, nor any of its agencies, political subdivisions, municipalities or school districts, shall enact, adopt or enforce any statute, regulation, ordinance or policy whereby homosexual, lesbian or bisexual orientation, conduct, practices or relationships shall constitute or otherwise be the basis of, or entitle any person or class of persons to have or claim any minority status, quota preferences, protected status or claim of discrimination. This Section of the Constitution shall be in all respects self-executing.”

${ }^{60}$ FRIEDMAN, supra note 34, at 148.

${ }^{61}$ Evans v. Romer, 882 P.2d 1335 (Colo. 1994).

${ }^{62}$ Romer v. Evans, 517 U.S. 620 (1996). 
in the century to use the boycott to achieve political or social ends. In the 1930s, the Catholic Church, in response to what they viewed as "vulgarity and coarseness" in the movies, ${ }^{63}$ instituted a boycott against motion "pictures which violated the Motion Picture Production Code." 64 Using the clout and social network of the Church, a pledge was read and distributed to between 7 and 9 million Catholics in America, from over a third to nearly half of all the Catholics in America. ${ }^{65}$ Takers of the pledge joined the "National Legion of Decency," pledged not to watch these movies, and pledged to recruit more people to the legion, ${ }^{66}$ that is, pledged to continue and grow this boycott. The boycott was not limited to one religious denomination. Rather within just a few months, over 7 million individuals of all different religious backgrounds were participating in the boycott. ${ }^{67}$ This external pressure proved to be more successful than even government regulation ${ }^{68}$ with the motion picture association continuing, even today, to be regulated by an independent oversight body that assesses the content of movies in terms of violence, sex, and profanity. ${ }^{69}$

The use of the boycott to influence societal values was not a singular incident isolated to the pre-war period. In the late 1980s and early 1990s, the America Family Association (AFA) and Christian Leaders for Responsible Television undertook a series of boycotts of advertisers in order to influence the content of television programming. ${ }^{70}$ The former editor of the National Boycott News, Todd Putnam, flagged this group's work as being responsible for an "impressive list of boycott victories" in persuading advertisers to shift the content of the shows they support to include less sex, violence, and profanity or to change their advertising strategies to instead support programming with values that conformed with those of the AFA. ${ }^{71}$ They later led a boycott of the television show, Ellen, which featured a lesbian main character, which some have pointed to as leading to the program's cancellation. ${ }^{72}$ AFA's boycotts were not limited to media content. Making up the flip-side of the Cracker Barrel and Phillip Morris boycotts discussed above, in 1996, the AFA, joined by the Southern

\footnotetext{
${ }^{63}$ FRIEDMAN, supra note 34, at 160.

${ }^{64}$ Ruth A. Inglis, FreEdom OF THE Movies 121 (1947).

${ }^{65}$ FrIEDMAN, supra note 34, at 161.

${ }^{66}$ Id. at $160-61$.

${ }^{67}$ Gregory D. Black, Hollywood Censored: The Production Code Administration and the Hollywood Film Industry, 1930-1940, 3 FILM HISTORY 167, 177 (1989).

${ }^{68}$ INGLIS, supra note 64, at 125.

69 What Each Rating Means, Motion PiCture Association of America, http://www.mpaa.org/ratings/what-each-rating-means (last visited Feb. 29, 2012).

${ }^{70}$ FRIEDMAN, supra note 34 , at 170

${ }^{71}$ Id.

${ }^{72}$ Bill Carter, Fate of “Ellen”, N.Y. TIMES, Feb. 25, 1998.
} 
Baptist Conference, launched a boycott targeting the Walt Disney Company to protest their "gay friendly" policies. ${ }^{73}$

\section{B. The Political Boycott in the Courts}

In keeping with the storied history of the political boycott, the federal courts have recognized and protected political consumer boycotts, since the ascension of these cases at mid-century. Non-labor political boycotts were not generally targeted by litigation in the early part of the twentieth century, however, at mid-century, political boycotts were targeted both for damages and injunctions. The political boycott was upheld in the Circuit Courts far before the issue was finally addressed at the Supreme Court.

The Fifth Circuit, which from 1891 through 1981 covered most of the former Confederacy, saw the bulk of the political boycott cases. ${ }^{74}$ In late 1967, the Greenwood Movement was organized in Leflore County, Mississippi, to combat racial discrimination. Following the assassination of Dr. Martin Luther King, the Movement began a boycott in order to "eliminate segregation and discrimination; to make all men free; to create fair employment practices."75 Because of scattered acts of violence concurrent with the boycott, the state court enjoined all picketing, persuasion of others to picket, congregating in the public to do anything "directly or indirectly" to persuade others not to do business with the merchants, and announcing the names of anyone who entered the business establishments. $^{76}$ The Fifth Circuit affirmed the grant of a federal injunction against the Mississippi state injunction to "vindicate clear First Amendment rights" inherent in the Greenwood boycott. ${ }^{77}$ The court determined that the rights involved in the Greenwood boycott were " $[\mathrm{t}] \mathrm{he}$ most important public rights . . . political rights which determine the composition of government and the direction of government policy."78

Ten years later, the federal courts again considered a state injunction of a political boycott. In Henry v. First National Bank, ${ }^{79}$ the Fifth Circuit first addressed the boycott that would go on to become the substance of the Supreme Court decision recognizing the right to the political boycott. The

${ }^{73}$ FRIEDMAN, supra note 34, at 170-71.

${ }^{74}$ At mid-century, the Fifth Circuit had jurisdiction over Florida, Georgia, Alabama, Mississippi, Louisiana, and Texas. In 1981, the Circuit was split into the Fifth and the Eleventh Circuits, with Mississippi, Louisiana, and Texas remaining in the Fifth.

${ }^{75}$ Machesky v. Bizzell, 414 F.2d 283, 285 (5th Cir. 1969).

${ }^{76}$ Id.

${ }^{77}$ Id. at 287.

${ }^{78}$ Id. at $288-89$.

79595 F.2d 291 (5th Cir. 1979). 
Mississippi state court had issued an injunction and awarded damages from the boycotters stemming from the seven-year boycott in Claiborne County, Mississippi. In Henry, the Fifth Circuit affirmed the district court injunction against enforcement of the state court injunction and damages award. Stressing the likelihood of the boycotts of prevailing on the merits of their First Amendment claim, the court noted that the boycott at issue did not arise from "parochial economic interest" but rather that all of the activity stemmed from the effort for "elimination of racial discrimination in the town." ${ }^{80}$ For the court, the political nature of the boycott "differentiate[d] this case from a boycott organized for economic ends, for speech to protest racial discrimination is essential political speech lying at the core of the First Amendment."

As the use of the boycott spilled out of the context of racial discrimination, so too did federal court recognition of the political boycott as core First Amendment speech. In 1977, after a number of defeats in state legislatures, the National Organization of Women launched a boycott of the states that had not yet ratified the ERA, calling on supporters to refuse to travel to these states and to conduct no business with companies therein. ${ }^{82}$ Missouri, eschewing the state courts entirely, brought an action for injunctive relief against NOW in federal court, asserting violations under state antitrust law and the Sherman Anti-Trust Act. ${ }^{83}$ The district court denied relief and the Eighth Circuit affirmed, stressing that the right of groups to undertake activity aimed at influencing the government was within the core of the First Amendment guarantee of the right to petition for redress of grievances. ${ }^{84}$ The court held "that NOW's boycott activities are privileged on the basis of the First Amendment right to petition and the Supreme Court's recognition of that important right when it collides with commercial effects of trade restraints. ${ }^{, 85}$

Weighing in on a case sixteen years after the boycott had begun, and ten years after the boycott's conclusion, the Supreme Court decided NAACP v. Claiborne Hardware, ${ }^{86}$ as the question of the First Amendment status of the political boycott finally made it to the Court in 1982. Though held to be constitutionally protected in a unanimous result penned by Justice Stevens, the lack of a direct statement declaring the boycott's own protected status has perhaps left the door slightly open for today's critiques of the boycott, if

\footnotetext{
${ }^{80}$ Henry, 595 F.2d at 303.

${ }^{81} \mathrm{Id}$.

${ }^{82}$ FRIEDMAN, supra note 34, at 152.

${ }^{83}$ Missouri v. Nat'l Org. for Women, 620 F.2d 1301, 1302 (8th Cir. 1980).

${ }^{84} \mathrm{Id}$.

${ }^{85} \mathrm{Id}$. at 1319 .

${ }^{86} 458$ U.S. 886 (1982).
} 
only as a rhetorical matter. ${ }^{87}$

As mentioned above, the Claiborne Hardware boycott began in 1966 after city leaders in Port Huron, Mississippi rebuffed demands for racial justice. The state court imposed damages liability on the basis of common-law tort and issued a permanent injunction of all boycott activity. ${ }^{88}$ The state court determined, "If any of these factors-force, violence, or threats-is present, then the boycott is illegal regardless of whether it is primary, secondary, economical, political, social or other." ${ }^{\text {"89 }}$ The Court determined that "[e]ach of these elements[-refusal to patronize, speeches, and nonviolent picketing-] of the boycott is a form of speech or conduct that is ordinarily entitled to protection under the First and Fourteenth Amendments." 90

To arguments that the boycott should have lost its protected character because of social pressure and coercion, the Court was explicit, "Speech does not lose its protected character, however, simply because it may embarrass others or coerce them into action."91 In fact, these embarrassing or coercive effects of the speech are innate in its message. The Court considered the concept of coercive impact to be intrinsic to any speech aimed at persuasion: "The claim that the expressions were intended to exercise a coercive impact on respondent does not remove them from the reach of the First Amendment. Petitioners plainly intended to influence respondent's conduct by their activities; this is not fundamentally different from the function of a newspaper."92

The political boycott is the stuff of democracy-construction, recognized by the Court as "rest[ing] on the highest rung of the hierarchy of First Amendment values."93 The Court recognized that the boycott at issue was one aimed at changing the political and social order, thus different than a merely economic boycott. ${ }^{94}$ "Through speech, assembly, and petition-

87 While the holding of NAACP $v$. Claiborne Hardware recognizes the First Amendment-protected status of the boycott, in the opinion, the court addressed all of the elements of the boycott, but failed to make a strong statement about the boycott itself. NAACP v. Claiborne Hardware Co., 458 U.S. 886, 907 (1982) ("Each of these elements of the boycott is a form of speech or conduct that is ordinarily entitled to protection under the First and Fourteenth Amendments.”)

${ }^{88} \mathrm{Id}$. at 893.

${ }^{89} \mathrm{Id}$. at 895 .

${ }^{90} \mathrm{Id}$. at 907.

${ }^{91} \mathrm{Id}$. at 910.

${ }^{92}$ Id. at 911 (citing Schneider v. State, 308 U.S. 147 (1939); Thornhill v. Alabama, 310 U.S. 88 (1940)).

93 Claiborne Hardware, 458 U.S. at 913 (citing Carey v. Brown, 447 U.S. 455, 467 (1980)) (internal quotation marks omitted).

${ }^{94}$ While the Court recognized the right of the state to regulate economic activity, a right that is likely to suffice when a state seeks to limit economic boycotts or expressly 
rather than through riot or revolution-petitioners sought to change a social order that had consistently treated them as second-class citizens." "95 The real complaint over the boycott is not about the fact that it is clearly expressive activity under the First Amendment, but rather the question is one of the impactfulness of the speech, which is not an appropriate ground for distinction under the Constitution. ${ }^{96}$ The heart of Claiborne Hardware shows that the boycott does not require the present day arc of campaign finance jurisprudence to uphold its democratic legitimacy under the First Amendment, but, as this Article argues, current campaign finance jurisprudence underscores the discontinuity of arguing for unlimited campaign and independent spending and against the boycott. ${ }^{97}$

\section{The Political Boycott And TheOries of The First AMENDMENT}

It is well established that the First Amendment covers expressive conduct. $^{98}$ Both federal court precedent and the very values that underpin First Amendment jurisprudence underscore the importance of awarding political boycotts this protected status. The three main theories underlying the First Amendment are (1) the marketplace of ideas; (2) democracy/selfgovernance; and (3) self-expression/autonomy. Each of these rubrics confirms that the political boycott lies at the heart of the First Amendment.

\section{A. Marketplace of Ideas}

Justice Oliver Wendell Holmes first formulated the "marketplace of ideas" in his dissent in Abrams $v$. United States, ${ }^{99}$ often considered the birthplace of modern First Amendment doctrine. ${ }^{100}$ Justice Holmes asserted that truth can only be tested by "free trade in ideas-that the best test of truth is the power of the thought to get itself accepted in the competition of

anti-competitive conduct, they "[did] not find a comparable right to prohibit peaceful political activity such as that found in the boycott in this case.” Id. at 913.

${ }^{95} \mathrm{Id}$. at 912.

${ }^{96}$ See, e.g., McIntyre v. Ohio Elections Comm’n, 514 U.S. 334, 347 (1995) ("Urgent, important, and effective speech can be no less protected than impotent speech.”); New York Times Co. v. Sullivan, 376 U.S. 254, 273, (1964) (criticism “does not lose its constitutional protection merely because it is effective”).

${ }^{97}$ The groups that argue for unlimited campaign spending often overlap with those that hold up the boycott as a form of threats, harassment or reprisals. See, e.g., Wisconsin Right to Life, Inc. v. F.E.C., 546 U.S. 410 (2006) and ProtectMarriage.com v. Bowen, 599 F. Supp. 2d 1197, 1198 (E.D. Cal. 2009) (both lead by James Bopp, Jr.).

${ }^{98}$ See, e.g., Texas v. Johnson, 491 U.S. 397 (1989); Spence v. State of Wash., 418 U.S. 405 (1974).

99250 U.S. 616 (1919).

100 See Post, supra note 25, at 2356-58. 
the market."101 This estimation of the importance of the market to test ideas constantly recurs in First Amendment case law. The Court has oft said that " “[i]t is the purpose of the First Amendment to preserve an uninhibited marketplace of ideas in which truth will ultimately prevail.” “102 The conception of the marketplace of ideas is one where different sets of ideas are all released to the public sphere to vie for supremacy. The truth-testing crucible of the marketplace of ideas allows the truth, the best ideas, to rise to the top.

Boycotts fit into the marketplace of ideas theory perhaps even better than other, more traditional, forms of expressive political conduct because their success and continuation depend wholly on convincing others. An individual can keep on leafleting in order to spread his or her idea, even if convincing no one else. The idea still pervades the marketplace in its printed word. But since the message of the boycott is conveyed not expressly in words, if the boycott fails, the message ceases to be conveyed and can instead give support to the opposite message. Regardless of the internal motivations of any given boycotter, a boycott simply is not a boycott without common support; it devolves into individual market choice without the same expressive impact. ${ }^{103}$

Boycotts by their very nature are public. As a practical matter boycotts cannot actually be private; without additional members, there is little utility in even launching one. Thus, a boycott asserts itself into the public sphere to be tested in the marketplace of ideas. In an "uninhibited marketplace," the truth of a boycott can be tested. If the originators of a boycott cannot persuade others to the rightness - the truth — of their position then the boycott will fail, and little will be said in support of their cause by the failed attempt. In fact, a failed boycott credits the side being targeted because the targets can easily illustrate the fact that the idea waged against them has not "ultimately prevailed." A failed boycott failed to persuade others - or a sufficient number of others - to have staying power; it failed the truth test of the marketplace.

While the "marketplace of ideas" jurisprudence speaks in terms of

101 Abrams v. United States, 250 U.S. 616, 630 (1919) (Holmes, J., dissenting).

102 Turner Broad. Sys., Inc. v. FCC, 507 U.S. 1301, 1304 (1993) (quoting Red Lion Broad. Co. v. FCC, 395 U.S. 367, 390 (1969)); see also Hustler Magazine, Inc. v. Falwell, 485 U.S. 46, 52, 56 (1988).

${ }^{103}$ While a single individual could indeed continue a boycott on their own, no one would know that is what they are doing unless they expressly made mention of it. While the decision not to buy can certainly still be made by one individual, without public buy in such a boycott loses much of its message-conveying function. A boycott with common support, however, conveys the message to the one being boycotted as they see it in their actual experience, either through physical pickets or otherwise inexplicably declining receipts. 
truth, a contestable goal when arguing policies rather than facts, the Court has expressly recognized that this conception of the First Amendment and the protections it offers is wider than just rational discussion. "It extends to more than abstract discussion, unrelated to action. The First Amendment is a charter for government, not for an institution of learning. 'Free trade in ideas' means free trade in the opportunity to persuade to action, not merely to describe facts." ${ }^{\prime 104}$ The boycott is precisely a means to persuade others to action, both those being targeted and those inspired to join. This "free trade" in persuasion is why the boycott finds a natural home under the marketplace of ideas theory of the First Amendment. Where the "truth" being tested is not of fact but of belief or opinion, the "truth" is established by common acceptance, the de rigueur of a successful boycott and, in fact, of every decision in a democratic society. The entire system is built upon the concept of people agreeing to live in certain ways with the majority prevailing, whether via their vote in an election or via their market choice in a boycott. In addition, even when a boycott does not necessarily achieve its ultimate end, it remains a vehicle for forcing the dissemination of an idea. Boycotts make perhaps otherwise latent dissent visible to a greater number of participants in the marketplace of ideas, highlighting not only their position but also the very debate.

Claims that boycotts fail to satisfy the values of the marketplace of ideas because they coerce others into not speaking, thus depriving the market of those ideas, must fail. Such claims give the boycott too much credit. Boycotts are only one voice among many, they are a costly form of speech for the speaker, and, within the market, they can be combated with further speech. ${ }^{105}$ As the Court has often made clear, just because one voice is louder does not mean that other voices are being silenced, and even if the danger of drowning out arises, the way to combat it has never been to temper the louder voice. ${ }^{106}$ In fact, in other contexts, the Court has held that just because a voice is being drowned out by louder voices, the state does not have the ability to silence these louder voices in response. They have been explicit that "the concept that government may restrict the speech of

104 Thomas v. Collins, 323 U.S. 516, 537 (1945).

105 See, e.g., Thornhill v. Alabama, 310 U.S. 88, 105 (1940) (holding that expression of ideas can only be abridged when there is the "clear danger of substantive evils aris[ing] under circumstances affording no opportunity to test the merits of ideas by competition for acceptance in the market of public opinion”). See also Declaration of Sarah E. Troupis in Support of Plaintiffs' Motion for Preliminary Injunction, Doc. 19, at Ex. BC, ProtectMarriage.com v. Bowen, No. 09-00058 (E.D. Cal. 2009) (illustrating further speech combating a boycott).

${ }^{106}$ Buckley v. Valeo, 424 U.S. 1, 48-49 (1976) ("But the concept that government may restrict the speech of some elements of our society in order to enhance the relative voice of others is wholly foreign to the First Amendment.”). 
some elements of our society in order to enhance the relative voice of others is wholly foreign to the First Amendment."107 While a successful boycott may appear to drown out another position, the remedy is not to silence the boycott but instead for those on the other side to endeavor to make themselves "louder."

In the case of boycotts, the marketplace element is twofold: persuasion of others to an idea and action in the actual marketplace. Boycotts illustrate the marketplace of ideas in the idea-forcing way discussed, but are also a classic instantiation of this market. By tying ideas directly to market choice, boycotts provide perhaps the best tangible example of the marketplace of ideas.

While the mingling of the market and the political via boycotts may give some pause, there already exists a highly structured realm governed by extensive legal doctrine where the economic and political coexist: campaign finance. This area of the law has something to teach us about when and how the economic and political can interact. In its most recent campaign finance case, Citizens United v. FEC, the Court expressly rejected the idea that resources from the economic marketplace should not be deployed in the political marketplace. ${ }^{108}$ Political speech is "indispensable to decisionmaking in a democracy," ${ }^{109}$ and in support of this fact, the Supreme Court overturned Austin v. Michigan Chamber of Commerce, ${ }^{110}$ which had upheld restrictions on corporate election spending because corporations used "'resources amassed in the economic marketplace' to obtain 'an unfair advantage in the political marketplace."”111

Citizens United permits corporations to use their market clout in order to influence the political process. So too should consumerscitizens - be allowed to deploy their resources amassed in the economic market to influence the political. As the Court has recently said, "political speech cannot be limited based on a speaker's wealth."112 This command illustrates that speech does not lose its protected character simply because it has economic roots. Boycotts simply operate in the opposite direction as the general concern of campaign finance law. Just as those with great economic resources can bring them to bear on the political sphere and not have their speech so limited, so too those with limited economic resources. Citizens United suggests all economic resources, not merely the expenditure

${ }^{107}$ Id.

${ }^{108}$ Citizens United v. Fed. Election Comm’n, 130 S. Ct. 876, 904-05 (2010).

${ }^{109}$ Id. at 904 (quoting First Nat'l Bank of Boston v. Bellotti, 435 U.S. 765, 777 (1978)).

${ }^{110} 494$ U.S. 652 (1990).

${ }^{111}$ Id. at 659 (quoting Fed. Election Comm'n v. Massachusetts Citizens for Life, Inc., 479 U.S. 238, 257 (1986)).

${ }^{112}$ Id. at 905. 
of large sums of money, can be used in the political marketplace. The boycott allows those whose main economic resource is their participation in the market as consumers to aggregate that resource, with other like-minded consumers, to influence the political marketplace. ${ }^{113}$ Austin may well have been considered the final wall holding the economic and the political spheres separate. With its demise, it becomes all the more apparent that the economic and political spheres are not separate in the modern American democracy, and all other examinations of our political system bear out that they truly are not. ${ }^{114}$ While the political boycott has always been at the core of First Amendment protection, the logic of Citizens United makes an apt analogy quelling doubts about the protected First Amendment status of boycotts on the grounds that they are coercive.

Political boycotts can be considered another incarnation of campaign spending, an independent withholding rather than an independent expenditure. Just as corporations spend, consumers must be allowed not to spend, as this is where their market power lies. If we take the First Amendment to protect the right of individuals to spend in the political context, ${ }^{115}$ this right simply cannot be predicated on being wealthy; its substance must be the right of all. Just as one wealthy contributor refusing to donate or patronize could cause different positions to be espoused, so too many individuals refusing to donate or patronize. With the current state of First Amendment jurisprudence in the realm of campaign finance, the actual market is expressly allowed to impact the marketplace of ideas. The political boycott is an inversion of the usual structure: allowing those with usually less market power-both in the actual market and that of ideas- to be heard. While it may seem less intuitive to consider lack of spending an exercise of wealth in political speech, it is beyond argument that the ability to boycott is a resource of the economic sphere, and in the case of political boycott, one that is being used to influence the political sphere, a

${ }^{113}$ Cf. Nixon v. Shrink Missouri Gov’t PAC, 528 U.S. 377, 414 (2000) (Thomas, J., dissenting) (Citizens "are aware that however great the confidence they may justly feel in their own good sense, their interests can be more effectually promoted by another than by themselves.”) (internal citations omitted). See also David A. Strauss, Corruption, Equality, and Campaign Finance Reform, 94 CoLUM. L. REV. 1369, 1379 (1994) ("people give to intermediary organizations precisely because they believe those organizations will transmit their views more effectively”).

114 See, e.g., Adam Liptak, Justices, 5-4, Reject Corporate Campaign Spending Limit, N.Y. TimeS, Jan. 22, 2010, at A; Eric Lipton, Mike McIntire \& Don Van Natta Jr., Large Donations Aid U.S. Chamber in Election Drive, N.Y. Times, Oct. 22, 2010, at A; Peter S. Goodman, Rule No. 1: Make Money by Avoiding Rules, N.Y. TIMES, May 23, 2010 (commenting on the "revolving door that sends denizens of Capitol Hill to highly paid jobs as lobbyists and bankers”).

${ }^{115}$ Buckley, 424 U.S. at 48-49; Citizens United v. Fed. Election Comm’n, 130 S. Ct. 876, 904 (2010). 
commingling of power that has been recognized and affirmed by the Court. $^{116}$

In an additional comparison to the campaign finance debates, boycotting takes a level of commitment and organization that is likely only to be displayed by those intensely committed to an idea. A larger, more diffuse group may oppose the very same idea or, more likely, have no strong feelings about it. However, the smaller group is more likely to organize and act collectively and, thus, more likely to have an impact. The intensity of the boycotters' views greatly impacts the success of the boycott. And it is this very intensity that opponents of a boycott try to frame as coercion, but such varying levels of intensity are the building blocks of representative democracy. ${ }^{117}$ Where compromise is required to accomplish anything, variant levels of intensity allow groups to coalesce around outcomes over which they otherwise disagree.

A successful boycott often requires those participants to pass by more convenient and less expensive options. Consider a boycott of a particular gasoline company: there will be points in time where the gasoline being offered by the boycotted company is considerably cheaper than the next available option; there will be times when a boycotter's car is nearly out of gas. An intensely committed boycotter will be willing to pay the extra ten cents a gallon or to risk the extra five miles. It is this level of intensity that makes a boycott successful, above and beyond a boycott where individuals only cleave to their commitment when it is convenient. Arguments opposing campaign finance limits laud the use of monetary contributions in order to gauge voter intensity.

[C]ontributions allow voters - that is, contributors-to register the intensity of their views. At the ballot box, a voter has a difficult time showing how enthusiastically she supports a candidate. She can vote for or against, or she can abstain. . . . By contrast, a contributor can spend her money in direct proportion to the intensity of her views. ${ }^{118}$

The same exact formulation can be said of the boycott: "[Boycotts] allow voters - that is, [boycotters] - to register the intensity of their views. . . By

116 Citizens United v. Fed. Election Comm’n, 130 S. Ct. 876, 903-05 (2010) (overruling Austin and the wall it constructed between the economic and political marketplaces).

117 Strauss, supra note 113, at 1376-77 (recognizing the power of groups with greater intensity of viewpoint as having "an organizational advantage over larger groups whose members have a more diffuse interest.”).

${ }^{118}$ Id. at 1374. 
contrast, a [boycotter] can [not] spend her money in direct proportion to the intensity of her views."119 The fact that a boycott privileges those positions with the most intensely committed following is no reason to stifle that speech. Numerous scholars have recognized that the small, intensely committed are the more likely to have success in the political marketplace. This is not a distinction to be lamented; it is simply a given in American democracy. ${ }^{120}$ The boycott is yet another illustration of this common phenomenon.

\section{B. Democracy/Self-Governance}

Another animating theory underlying the First Amendment is that of democratic self-government. Justice Brandeis expressed this theory most clearly in his concurrence, joined by Justice Holmes, in Whitney $v$. California, identifying speech as "essential to effective democracy."121 Harkening back to the founding, Justice Brandeis underscored the importance of unfettered speech to self-governance.

They believed that freedom to think as you will and to speak as you think are means indispensable to the discovery and spread of political truth; that without free speech and assembly discussion would be futile; that with them, discussion affords ordinarily adequate protection against the dissemination of noxious doctrine; that the greatest menace to freedom is an inert people; that public discussion is a political duty; and that this should be a fundamental principle of the American government. ${ }^{122}$

In American life, self-governance and democracy are the ends of any political expression.

In the legal academy, there are two main understandings of the First Amendment as a tool of democracy and self-governance. The first of these, birthed by the work of Alexander Meiklejohn, ${ }^{123}$ views those "communicative processes necessary to disseminate the information and ideas required for citizens to vote in a fully informed and intelligent way"124

${ }^{119} \mathrm{Id}$.

120 See, e.g., Mancur Olson, The Logic of Collective Action: Public Goods AND THE THEORY OF GROUPS (1965).

${ }^{121}$ Whitney v. California, 274 U.S. 357, 377 (1927) (Brandeis, J., concurring).

${ }^{122}$ Id. at 375.

123 MeIKLEJOHN, supra note 24.

${ }^{124}$ Post, supra note 25, at 2367. 
as within the First Amendment's protection. Meiklejohn conceives of the First Amendment as protecting that which citizens need to govern: protecting both the information that people need in order to make informed decisions and the speech that is necessary for people to learn how to govern, to participate in their democracy. ${ }^{125}$

The political boycott fits into either one of Meiklejohn's protected zones. Boycotts are information-forcing. They have no chance for success unless they spread their message, so they thus provide information useful to democratic decision-making. Furthermore, just like a protest, newspaper editorial, or even voting, the political boycott is by its nature a political act, meeting Meiklejohn's second conception. It is a classic form of political activism, requiring organization and engagement. A boycott not only allows for further action in a democracy but also is an action of construction of that very democracy.

The second conception of the First Amendment as a theory of democracy arose from a critique of Meiklejohn. This critique argues that under his theory, all that would merit protection would be allowing the information necessary to vote to be said once, without persuasive elements. Clearly, that is not the speech protection afforded by the First Amendment. Professor Robert Post has underscored the way in which the Meiklejohnian conception of self-governance does not coincide with First Amendment jurisprudence. Post argues for what he calls a "participatory" theory of the First Amendment, one that "does not locate self-governance in mechanisms of decision making, but rather in the processes through which citizens come to identify a government as their own."126 Though it diverges from Meiklejohn, the Postian theory of the First Amendment does not diverge from the practice of the boycott.

Boycotts engage individuals and require individual, political decisionmaking, allowing people to conceive of the government as their own. Under Post's conception of the participatory version of selfgovernance, the political boycott fits squarely into the core of First Amendment protection. "According to this theory, democracy requires that citizens experience their state as an example of authentic selfdetermination."127 This form of state construction requires individual construction, which is clearly borne out in a political boycott. The government is not a disparate entity operating separately from its citizens, and boycotts allow just this form of individual democratic engagement. While the Meiklejohn and Post theories of democracy focus on differing

\footnotetext{
${ }^{125}$ Alexander Meiklejohn, Political Freedom: The Constitutional Powers of THE PEOPLE 26 (1965).

${ }^{126}$ Post, supra note 25, at 2367.

${ }^{127}$ Id. at 2367-68.
} 
aspects, the quality of debate and the autonomy of individual citizens, respectively, ${ }^{128}$ they both present self-governance-possibly a vision of the two necessary aspects thereof_as an animating theory of the First Amendment.

The political boycott is deployed for a political reason-undertaken for the very same reason as an electoral campaign or impact litigation. A political boycott does not mandate any outcome, in fact, when consumers boycott to affect decisionmaking, "other individuals with equally intense feelings can respond roughly in proportion to their numbers." ${ }^{29}$ A boycott from one side does not close down debate or prevent further speech. ${ }^{130}$ For every boycott pushing to influence social or political decisions from one side, there can easily be one from the other. If others in the democracy disagree with the boycotters, they can boycott in kind or expressly patronize the boycott targets thus frustrating the boycotters' external effectiveness. A political boycott consists of individuals, through collective action, seeking to affect the social world around them — the very stuff of self-governance.

\section{Self-Expression / Autonomy}

The protections of the First Amendment are not created solely for the protection of the political sphere, but to "advance 'truth, science, morality, and arts in general.",131 Examination of the universe of First Amendment jurisprudence further illustrates that even these ends are not the only realm of protection. ${ }^{132}$ The final theory underlying the First Amendment is one of self-expression and autonomy. ${ }^{133}$ As Justice Brennan further stressed in his dissent in Dun \& Bradstreet v. Greenmoss Builders, Inc., ${ }^{134}$ there are many spheres, unrelated to politics or government where

${ }^{128}$ Id. at 2368.

${ }^{129}$ Harper, supra note 29, at 426.

${ }^{130}$ Brown v. Hartlage, 456 U.S. 45, 61 (1982) (quoting Whitney v. California, 274 U.S. 357, 374 (1927) (Brandeis, J., concurring)) (recognizing "[t]he preferred First Amendment remedy of 'more speech, not enforced silence'”).

${ }^{131}$ Curtis Publ'g Co. v. Butts, 388 U.S. 130, 147 (1967).

132 See, e.g., Brown v. Entm't Merchants Ass'n, 131 S. Ct. 2729 (2011) (protections for violent video games); United States v. Stevens, 130 S. Ct. 1577 (2010) (protection for depictions of animal cruelty); Virginia State Bd. of Pharmacy v. Virginia Citizens Consumer Council, Inc., 425 U.S. 748, 787 (1976) (recognizing protection for commercial speech).

${ }^{133}$ See, e.g., C. Edwin Baker, Scope of the First Amendment Freedom of Speech, 25 U.C.L.A. L. REV. 964, 966 (1978) ("protected conduct fosters individual self-realization and self-determination”); Thomas Scanlon, A Theory of Freedom of Expression, 1 PHIL. \& Pub. AfF. 204 (1972); Martin H. Redish, The Value of Free Speech, 130 U. PA. L. ReV. 591 (1982) (arguing for an "individual self-realization" theory of the First Amendment).

${ }^{134}$ Dun \& Bradstreet v. Greenmoss Builders, Inc., 472 U.S. 749 (1985). 
individual expression is paramount, and protected by the First Amendment. "[O]ur cases have never suggested that expression about philosophical, social, artistic, economic, literary, or ethical matters - to take a nonexhaustive list of labels - is not entitled to full First Amendment protection. The breadth of this protection evinces recognition that freedom of expression is not only essential to check tyranny and foster selfgovernment but also intrinsic to individual liberty and dignity and instrumental in society's search for truth."135 And it further is not just the high-minded realms of the liberal arts degree that are afforded protection once one leaves the world of the political, rather the Amendment's protection, perhaps to the chagrin of some, extends to individuals' choice of shampoo. $^{136}$

Apart from any productive end a boycott achieves, it may have internal effectiveness for those participating. ${ }^{137}$ A boycott can be a construction of the self. In a boycott, individuals are making decisions about how they personally live. ${ }^{138}$ In addition to those they hope to influence, boycotters are also making decisions that affect their own lives and future choices. While part of the political boycott is an aim to change the minds of others, another part is a personal conviction of each participant that his or her money shall not be available to be used in ways these boycotters deplore. There are many places that one can patronize, so part of boycotting is the choice not to have one's own money given to someone who may use it to support the cause the boycott is marshaled against. While a boycott depends on collectivity for attainment of its political ends, even in failure, it remains an expression of "a host of voluntary decisions by free citizens."139 Boycotts require their participants to make the decision not to patronize certain business. While in the political boycott this action is undertaken with the goal of influencing political and social structures or decisions, the participation itself defines each boycotter as an individual. Boycotters are making individual decisions that say something about who they are. Choosing never to patronize certain places can become a

${ }^{135} I d$. at 787 (Brennan, J., dissenting).

${ }^{136}$ Virginia State Bd. of Pharmacy v. Virginia Citizens Consumer Council, Inc., 425 U.S. 748, 787 (1976) (Rehnquist, J., dissenting) ("It is undoubtedly arguable that many people in the country regard the choice of shampoo as just as important as who may be elected to local, state, or national political office.”).

${ }^{137}$ Douglas A. Kysar, Preferences for Processes: The Process/Product Distinction and the Regulation of Consumer Choice, 118 HARV. L. REV. 525, 532 (considering consumer choices as "moral acts that have person significance irrespective of their instrumental effects.”) (2004); id. at 607.

${ }^{138}$ NAACP v. Claiborne Hardware, 458 U.S. 886, 888-89 (1982) (recognizing “a host of voluntary decisions by free citizens" as a "critical" factor to the boycott's success).

${ }^{139}$ Id. 
construction of identity for an individual. ${ }^{140}$ The fact that the choices involved in a boycott take place in the economic sphere does nothing to strip them of their self-constructing features. In fact, the Court has recognized that choices made in the economic sphere are some of the most important decisions in our society. ${ }^{141}$

\section{BOYCOTTS AND COMPELLED DISCLOSURE DOCTRINE}

The foregoing consideration of the boycott may appear backward looking, but the question of the political boycott is not just one of history. Boycotts are finding themselves at the forefront of current political debate, being deployed in litigation in an effort to illustrate harassment. ${ }^{142} \mathrm{~A}$ number of challenges in federal court to compelled disclosure regimes have surfaced in the past several years. Forced by precedent to accept the state's interest in disclosure, litigants have turned to as-applied challenges to these regimes arguing that their particular group has been subject to such "threats, harassment, or reprisals" that they are entitled to an exemption from these regimes. While boycotts have the power to visit real world costs upon those targeted, the First Amendment benefits and the ability to use further speech as the best method to combat a boycott outweigh these costs.

\section{A. Exemptions from Compelled Disclosure}

In the recent decisions in Citizens United v. FEC and Doe v. Reed, the Court once again upheld compelled disclosure regimes, but also reiterated the ability of groups to obtain as-applied exemptions based on a showing of "threats, harassment, or reprisals." "143 In these cases, the Court found that the states" interests in "transparency and accountability"144 and "providing the electorate information" 145 sufficient to uphold the compelled disclosure regimes under the "exacting scrutiny" test of Buckley v. Valeo, ${ }^{146}$ requiring a "“substantial relation,' between the disclosure requirement and a 'sufficiently important' governmental interest."147 Despite examples where

${ }^{140}$ Kysar, supra note 137, at 610, 615-16; see also Harper, supra note 29, at 415 ("Individuals frequently define themselves though the choices they exercise.")

${ }^{141}$ Virginia State Bd. of Pharmacy v. Virginia Citizens Consumer Council, 425 U.S. 748 (1976).

142 See supra note 5.

143 Buckley v. Valeo, 424 U.S. 1, 74 (1976).

${ }^{144}$ Doe v. Reed, 130 S. Ct. 2811, 2819 (2010).

145 Citizens United v. FEC, 130 S. Ct. 876, 914 (2010).

${ }^{146}$ Buckley, 424 U.S. at 64.

147 Doe v. Reed, 130 S. Ct. 2811, 2818 (2010) (quoting Citizens United v. Fed. Election Comm'n, 130 S. Ct. 876, 914 (2010) (quoting Buckley v. Valeo, 424 U.S. 1, 64, 66 
compelled speech by the government violates the First Amendment, ${ }^{148}$ compelled disclosure is a well-established example of an appropriate government function, one of both long pedigree ${ }^{149}$ and recent confirmation. ${ }^{150}$ The boycott is not rightly considered harassment, but should be protected First Amendment speech in its own right. Further, the political boycott is not mere collateral fallout to be suffered in order to enjoy the benefits of compelled disclosure. Rather political boycotts are valuable in themselves and should be celebrated. In an era in which money pours into political campaigns, ${ }^{151}$ the political boycott gives substance to the Court's findings on campaign finance making it into a two way street.

The Court has recognized a space for as-applied exemptions from generally applicable compelled disclosure regimes. In the pre-Buckley era, the two main cases underscoring the proposition of as-applied exemptions to compelled disclosure were cases where a Southern state or municipality was seeking to discover the membership of the NAACP. ${ }^{152}$ In that era, as discussed in Part I, there were extreme risks to the black community in the South-ones that simply do not exist for any groups in the current historical period-suggesting a careful eye must be turned to current claims of threats to assess their gravity. ${ }^{153}$ In order to obtain an as-applied exemption, the

(1976)).

${ }^{148}$ See Wooley v. Maynard, 430 U.S. 705 (1977) (displaying the state motto); Miami Herald Publ'g Co. v. Tornillo, 418 U.S. 241 (1974) (requiring newspaper publication of candidate reply); West Virginia State Bd. of Educ. v. Barnette, 319 U.S. 624 (1943) (requiring schoolchildren to salute the flag).

${ }^{149}$ Buckley v, Valeo, 424 U.S. 1 (1976).

${ }^{150}$ Doe, 130 S. Ct. 2811; Citizens United, 130 S. Ct. 876.

${ }^{151}$ See, e.g., TAYlor Lincoln, Pub. Citizen, Outside Job: Winning Candidate EnJoyed Advantage in UnRegulated Third-PARTy SPENDing IN 58 OF 74 PartySHIFTING CONTESTS (2010), available at http://www.citizen.org/documents/ Outside-JobReport-20101103.pdf; Michael Luo \& Griff Palmer, Outside Groups on the Right Flexed Muscles, N.Y. TIMES, Nov. 3, 2010.

${ }^{152}$ See NAACP v. Alabama ex rel. Patterson, 357 U.S. 449 (1958); Bates v. City of Little Rock, 361 U.S. 516 (1960).

${ }^{153}$ See, e.g., NAACP v. Alabama ex rel. Patterson, 357 U.S. 449, 462 (1958). In the Brief for the Petitioner in this case, they cite an instance of a state Senator telling people to "think white, talk white, buy and hire white." Pet. Br. 13 n.7. This is the only example among many that possibly comes close to a boycott—-the admonition to "buy. . .white." In fact, one of the examples proffered by the NAACP of the continuing harassment was the raids on the Tuskegee Civic Association with the Alabama Attorney General calling the civil rights boycott of the TCA an "illegal boycott." Pet. Br. 17 n.14. Furthermore, the circumstances surrounding the compelled disclosure in NAACP v. Alabama ex rel. Patterson were fraught with far more than economic reprisals. The events occurred in 1956, just four years after the first year in the history of the United States that no black individuals were lynched, and just barely a year after the murder of Emmitt Till. The 1959 decision came down the same year as the lynching of Mack Charles Parker in Mississippi. See generally CHRISTOPHER WALDREP, AFRICAN AMERICANS CONFRONT LYNCHING 
evidence offered must show a "reasonable probability" that the disclosure will subject the party's members or contributors to "threats, harassment, or reprisals from either Government officials or private parties.”" ${ }^{154}$ In all cases of harassment analysis, it is necessary that there be more than just a few fleeting examples, ${ }^{155}$ rather, a "pattern of threats" ${ }^{\text {"156 }}$ must be demonstrated. Lax requirements for the showing of "threats, harassment, or reprisals" would limit everyone's access to information. A weak standard would make it far too easy for any group to generate a few examples against themselves in order to avoid disclosure and obscure certain connections, a real concern recognized by the Court. ${ }^{157}$ A danger arises if courts accept an evidentiary showing in such an as-applied challenge that only amounts to "a handful of allegations of improper conduct . . . [inflated] by countless incidents in which [people] simply felt discomfort as being faced with vigorous but constitutionally protected expressions of disagreement."

\section{B. Government Interest in Compelled Disclosure in the Case of Initiatives and Referenda and the Need for the Boycott}

While Buckley predominantly focused on candidate-elections in determining the validity of the campaign finance regime including compelled disclosure, the informational interest recognized in Buckley, and again in Citizens United, remains a "sufficiently important" governmental interest in the context of issue elections. The petitioners in Doe argued that the informational interest was "insufficient" as "neither compelling nor important."159 An informational interest, however, may, in fact, be more important in the case of initiatives and referenda than in the case of candidate elections. In initiatives and referenda, the people are acting not just in government construction as when voting but as the government itself. Virtually all of the states and the United States itself legislate publicly. In fact, on the federal level, it is constitutionally required. ${ }^{160}$ This

(2009) (discussing the history of lynching in the United States).

154 Buckley, 424 U.S. at 74.

155 Id. at 29 (plaintiffs' showing of “random acts” insufficient to warrant as applied exemption).

${ }^{156}$ Id at 74.

157 The concern with covering up actual connections is neither speculative nor new. As the Court recognized in McConnell, groups were hiding behind "dubious and misleading names.” McConnell v. FEC, 540 U.S. 93, 197 (2003).

${ }^{158}$ Brief for Lambda Legal Defense and Education Fund., Inc. et al. as Amici Curiae Supporting Respondents, Doe v. Reed, 130 S. Ct. 2811 (2010) (No. 09-559); see also ProtectMarriage.com v. Bowen, No, 09-cv-00058, slip op. at 34-35.

${ }^{159}$ Doe v. Reed, No. 09-559, Pet. Br. 49.

160 Doe, 130 S. Ct. at 2833-34 (Scalia, J., dissenting) ("The public nature of federal lawmaking is constitutionally required. Article I, § 5, cl. 3 requires Congress to legislate in 
fact illustrates the longstanding interest in public accountability when it comes to the passage of legislation, an interest of grave importance in a democracy. In initiatives and referenda, individual voters serve as the legislators. The general electorate decides which issues will be taken upthrough ballot petitions - and which laws will be enacted-through the actual ballot questions. Arguably, initiatives and referenda are far weightier than candidate-elections, which merely stock the government for debate and compromise for legislation at some point in the future, while ballot questions make substantive legal changes on their face with no room for debate or compromise in the future. With initiatives and referenda, the whole process of governing is condensed into the campaign cycle, so public accountability serves an even more vital role than that considered in Buckley. This difference in structure from candidate elections, serves to bolster, not weaken, the informational interest in the case of both campaign finance and ballot petition disclosures.

In addition to their role as legislators, it is also "individuals advocating for a measure's passage or defeat"161 who can be considered akin to lobbyists in this scheme. This dual role of individuals, functioning in a similar way to both legislators and lobbyists, creates a two-fold reason for compelled disclosure in these cases. The standard American interest in public legislating, and the accountability and transparency that comes along with it, remains just as important when the people legislate as when do elected representatives. And just as Congress has required "lobbyists to disclose who is paying for the lobbyists services and how much,"162 individuals, in their role as lawmakers, have the same interest. Everyone voting on a ballot measure has an interest in knowing who has aimed to influence his or her vote. In Citizens United, the Court analogized compelled disclosure in campaign finance to that in lobbying. The "Court has upheld registration and disclosure requirements on lobbyists, even though Congress has no power to ban lobbying itself," it can "provide[] for a modicum of information from those who for hire attempt to influence legislation or who collect or spend funds for that purpose"163 Perhaps even more so than in campaign finance, the necessity of lobbyist disclosure is

public: 'Each House shall keep a Journal of its Proceedings, and from time to time publish the same, excepting such Parts as may in their Judgment require Secrecy; and the Yeas and Nays of the Members of either House on any question shall, at the Desire of one fifth of those Present, be entered on the Journal.' State constitutions enacted around the time of the founding had similar provisions. See, e.g., Ky. Const., Art. I, § 20 (1792); Ga. Const., Art. I, § 15 (1798).”)

${ }^{161}$ Protectmarriage.com v. Bowen, 599 F. Supp. 2d 1197, 1208 (E.D. Cal. 2009).

${ }^{162}$ Id. (quoting CPLC v. Getman, 328 F.3d 1088, 1106 (9th Cir. 2003)).

163 Citizens United, 130 S. Ct. 876, 915 (2010) (quoting United States v. Harriss, 347 U.S. 612, 625 (1954)). 
well recognized. ${ }^{164}$ In initiatives and referenda, donors and advocates are more akin to lobbyists than in candidate-elections, as all of the people are the legislators.

Furthermore, disclosure requirements serve a signaling function, just as does party ID in candidate elections. ${ }^{165}$ These requirements provide information on where the support for a measure is coming from. "Much of the contemporary research on direct democracy has concluded that campaign spending is the best predictor of the success of ballot measures." 166 In light of this fact, the electorate has an interest in campaign finance disclosure so they know what forces are aligned behind any position advocated in the fight over a ballot initiative. This interest does not stop with large corporate donations either. If, for example, the bulk of the financial support for an initiative came from out of state-regardless as to whether this was in the form of a few large or countless small donationsthis is information of interest to voters in making their decisions. The district court in Bowen recognized just this interest, noting that voters would be interested in knowing whether a given initiative "was funded by the citizens it is intended to affect or by out of state interest groups and individuals." ${ }^{167}$ Additionally, such disclosure allows all citizens to know whom to engage on issues of great importance to the electorate, ${ }^{168}$ thus supporting disclosure, perhaps even more strongly, in both the case of ballot petitions and campaign finance in direct democracy. In fact, these "disclosure requirements actually serve to facilitate discourse.",169

At its core, the political boycott is a petition to the government for redress of grievances, ${ }^{170}$ albeit a petition that counts people in a way other than by mere signature. Harper's conception of the right to petition as being insufficient to protect the political boycott ${ }^{171}$ holds far less sway when

${ }^{164}$ Harriss, 347 U.S. 612.

165 See, e.g., Bruce CAin, John Ferejohn \& Morris Fiorina, The Personal Vote: CONSTITUENCY SERVICE AND Electoral InDEPENDENCE 9 (1987) (commenting on the importance of party ID in voter choice).

${ }^{166}$ Richard Braunstein, The Impact of Campaign Finance on Ballot Issue Outcomes, in Initiative-Centered Politics: The New Politics of Direct Democracy 77 (David McCuan \& Steve Stambough eds., 2005).

${ }^{167}$ Bowen, 599 F. Supp. 2d at 1224, n.11.

168 Doe v. Reed, No. 09-559, Pet. Br. 49 (identifying referenda as being about “issues [that] are too important to be left to legislatures”).

${ }^{169}$ Bowen, 599 F. Supp. 2d at 1219.

170 See NAACP v. Claiborne Hardware, Co., 458 U.S. 886, 909 (1982) ("[A] a peaceful march and demonstration was protected by the rights of free speech, free assembly, and freedom to petition for a redress of grievances.”) The Court's decision framed the boycott as further petition for redress of grievances, in addition to the actual physical petition, the dismissal of which began the boycott.

${ }^{171}$ Harper, supra note 29, at 417-20. 
we consider ballot initiatives and referenda. Where the government is composed of the public, the political boycott serves directly as a petition to "governmental action." 172

Why does a petition have any impact on the government or other decision makers? The fact of aggregation so presented can alert its target to the wants of a large swath of the population. Boycotts function in just this way. In the case of initiative and referenda, it becomes ever more clear that a boycott expressly is a petition to redress grievances. Where private individuals and not legislators are functioning in the law-making role, there is not, at first glance, a place to present petitions for redress. There are no constituent services aides or offices in the state house. Instead, one of the main places this government of private citizens lives is within the economic sphere, the area where virtually all individuals spend the bulk of their time. In the case of an initiative or referendum, there simply is no one else for citizens to petition besides their fellow citizens. If the courts determined that in these cases boycotts could be counted as harassment, they would wholly remove the right to petition the government for redress of grievances whenever legislation was passed via these citizen ballot measures. Boycotts give citizens voice in relation to other citizens and serve as critical tools of petition in cases of initiatives and referenda.

The results of direct democracy are far more stubborn than mere legislative enactments. In California, for example, initiatives are "written in stone."173 They may only be amended or repealed via another initiative, so the only government to which people can address themselves is to the supporters of the initial proposition, either before-in an attempt to defeat-or after-in an attempt to repeal or amend-its passage. Even in states where the legislature has some power over legislation passed via initiative and referenda, the understanding of the people as the government persists. Notably, other states have restrictive language limiting their legislatures' ability to either amend or repeal, and even in states without

${ }^{172}$ Id. at 419.

173 People v. Kelly, 222 P.3d 186, 200 (Cal. 2010). CAL. CONST. art. 2, § 10(c) ("The Legislature may ... amend or repeal an initiative statute by another statute that becomes effective only when approved by the electors unless the initiative statute permits amendment or repeal without their approval.”). Arizona also prevents legislative repeal or amendment of initiatives. ARIZ. CoNST. art. 4, Part 1, § 1(6)(B)-(C) ("The legislature shall not have the power to repeal an initiative measure approved by a majority of the votes cast thereon or to repeal a referendum measure decided by a majority of the votes cast thereon. . . . The legislature shall not have the power to amend an initiative measure approved by a majority of the votes cast thereon, or to amend a referendum measure decided by a majority of the votes cast thereon, unless the amending legislation furthers the purposes of such measure and at least three-fourths of the members of each house of the legislature, by a roll call of ayes and nays, vote to amend such measure.”); see also Perry v. Brown, No. S189476, slip op. at 5, 53 (Cal. Nov. 17, 2011). 
these limitations, legislative action on initiative-passed legislation is quite rare. $^{174}$ These statutory and constitutional limitations and the rarity of actual practice in places where the legislature is not so limited underscores the vital importance in keeping open the channels of petition to other members of the electorate. As proponents of the use of initiative and referenda are wont to mention, the matters tackled through these forms of legislating are those "too important to be left to legislatures." ${ }^{175}$ In matters of such grave importance, it is all the more critical that all avenues of petition are left open to the citizenry. Beyond the protection recognized in Claiborne Hardware, it is even more important in the case of initiative and referenda that boycotts be recognized for what they truly are-petition of the government for redress of grievances, not harassment.

Michael Harper analogizes the political boycott to electoral voting. He argues that "[b]y threatening to remove elected public officials from office, electoral voting may "coerce" those officials to reject political causes in which they might believe. Yet such "coercion" is an accepted part of governmental decisionmaking." "176 He goes on to legitimate boycott of "businessmen who fill important public roles of significant political influence" though the same analogy. ${ }^{177}$ While Harper's analogy is a useful starting point, it does not cover the whole field. Unlike Harper's conception, we must recognize boycotts as legitimate in any political deployment, not just of those "businessmen" in important roles; increased democratization must recognize the roles played by all, not just those with the most clout. Moreover, in the case of initiative and referenda, every actor necessarily fills a "role[] of significant political influence" just as every legislator and lobbyist fill such roles.

Elected officials listen because of the inherent risks in the decisions they make; if an elected official disappoints a large enough swath of the electorate, they will not find themselves to be an elected official much longer. Similarly, the boycott gives similar voice. ${ }^{178}$ If there is no risk for the proponents of an initiative, they have no motivation to listen to those voicing a different opinion just as the risk of losing elections causes elected officials to listen to their constituents. This act of petition via boycott does not force particular action, but just as any petition serves as an alert to the

${ }^{174}$ Philip L. Dubois \& Floyd F. Feeney, California Policy SEMinar, Improving THE CALIFORNIA INITIATIVE PROCESS: OptIONS FOR CHANGE 8 (1992).

175 Doe v. Reed, No. 09-559, Pet. Br. 49.

${ }^{176}$ Harper, supra note 29, at 425.

${ }^{177}$ Id.

${ }^{178}$ While Albert O. Hirschman's concepts of voice and exit are often used in regard to a polity, his work initially conceived of these concepts within firms. ALBERT O. Hirschman, ExiT, Voice, AND LOYALTy (1970). Thus, it is a natural fit to think of the boycott, a partially economic activity, in terms of voice and exit. 
existence of opposition and, depending on the degree of opposition, can be influential. The petition-boycott provides information to these citizen legislators that they may have previously lacked about the position of those most greatly impacted or those who feel most strongly against the measure.

Just as different electoral factions can petition for different positions, and thus the elected official can weigh the support of each side, those opposed to the boycotters' aims can purposefully patronize the establishment in question, thus allowing the producer to be aware of those who support his political and social decisionmaking. ${ }^{179}$ Likewise, if enough people patronize instead of boycott, regardless of whether or not they are motivated by opposition to the boycott, the position of the boycotters is drowned out by having no impact of the producer's bottom line. Supporters of a measure, whether via donation, petition signature, or vote, do not all possess the same level of support for the issue, nor have they necessarily thought the issue through.

In a democracy, the ideal freedom is more than just the freedom to be left alone, rather democracy demands “" public freedom'-the ability to participate actively in the basic societal decisions that affect one's life.”180 This critical form of freedom is highly important in the case of initiatives and referenda. When deploying these important governance tools, everyone should not simply be left alone to determine the fate of the whole polity. Decisions must not be made without interaction among decision makers, advocates, and ordinary citizens-groups that overlap to a greater degree in the case of initiatives and referenda than in the case of candidate-elections.

\section{A RESPONSE TO AdMINISTRABILITY CONCERNS}

There are some contexts where different sets of concerns are ascendant when dealing with the boycott, even some that may claim to have political ends. The question of administrability is a serious one but does not undermine the basic argument here because political boycotts deployed by consumers do not implicate the same concerns as boycotts and other economic action taken by producers or others with particularized market clout. ${ }^{181}$ Two recognized contexts where the calculus regarding the boycott is different than when consumers deploy political boycotts are economic and labor boycotts.

${ }^{179}$ Protectmarriage.com v. Bowen, No. 09-CV-00058, Troupis Decl., Exh. BC.

${ }^{180}$ Gerald E. Frug, The City As A Legal Concept, 93 HARV. L. REV. 1059, 1068 (1980) (quoting HANNAH ARENDT, ON REVOLUTION 114-15, 119-20 (1962)).

${ }^{181}$ Harper, supra note 29, at 426-27. 


\section{A. Economic Boycotts}

Boycotts of all types are sometimes framed as inherently anticompetitive; ${ }^{182}$ they put pressures on markets that are different than if the market was left to function simply as an economic phenomenon. A boycott without the intention of leading to political change but with the express intention of changing economic relationships is a different creature than the political boycott and one already dealt with by federal law. ${ }^{183}$ However distinguishing when "anti-competitive" restraint, that is, boycotts, should be immune from anti-trust or similar liability ${ }^{184}$ is not an insurmountable hurdle.

Before delving further into the question of political versus economic restraint, I pause at the conception of defining boycotts as anti-competitive. With the political boycott, petitioners are not engaging in anti-competitive behavior but, rather, asking the boycotted target merely to compete on a different set of terms. There are countless producers in the marketplace-in very few industries is there only a choice of one-and the political boycott demands competition in other ways besides merely price or product, ways that may be more important to certain consumers. ${ }^{185}$ In a free market, it is the decision of each participant, including consumers, to decide the terms held most important. Any boycott asks for sacrifice from those participating in the boycott; so for these consumers, there is something that outweighs the cost or conveniences of a given product when they are making their marketplace decisions. A political boycott, among other things, shifts the terms of competition.

The main distinguishing factor between an economic and a political boycott are the ends aimed for by the boycotters. If the boycott is undertaken because of competition between the targeted business and the boycotters or because of any similar parochial interest, this is an economic boycott and can be kept outside of the strong First Amendment protection recognized by the Supreme Court for the political boycott, and so set aside for the purposes of this article. ${ }^{186}$ Some may clamor against this distinction, but regardless of one's views of such boycotts, their different jurisprudential status allows them to be left on the outskirts of this current discussion. Nevertheless, in setting them aside, we must consider how to distinguish

${ }^{182}$ See, e.g., F.T.C. v. Superior Court Trial Lawyers Ass'n, 493 U.S. 411 (1990) (boycott constituted restraint of trade).

${ }^{183}$ Sherman Anti-Trust Act, 15 U.S.C. §§ 1-7.

${ }^{184}$ See, e.g., Einer Elhauge, Making Sense of Antitrust Petitioning Immunity, 80 CALIF. L. REV. 1177 (1992).

${ }^{185}$ Cf. Kysar, supra note 137, at 531, 584.

${ }^{186}$ NAACP v. Claiborne Hardware Co., 458 U.S. 886, 913-15 (1982). 
between political and economic boycotts.

Einer Elhauge makes this distinction with a focus on the financial interests of those applying the restraint, in this case the boycott. He argues that private motivations are an inappropriate impetus behind a restraint, while public motivations are licit. He would allow for public decisionmaking in the launch of a boycott, but would find anti-trust liability if private decisionmaking prevailed. ${ }^{187}$ For Elhauge, “'[p]rivate decisionmaking' is thus merely a shorthand for financially interested decisionmaking, and 'public decisionmaking' is a shorthand for decisionmaking that is financially disinterested and politically accountable.” ${ }^{888}$ Elhauge has little interest in the motive of the boycottthat is, whether it is deployed to achieve a political or social end-but bases his theory solely on the financial interests of those deploying the restraint. In this way, Elhauge fails to present a clear picture of which boycotts should fall into the protection outlined in Claiborne Hardware as political boycotts. The distinction should be based upon whether the boycott is aiming to influence political or social change. While Elhauge's focus on identity helps answer the question of administrability, it is not determinative of a boycott's ends. The identity of the boycotters is a telling piece of evidence as to whether the boycott is political or economic-the who will often answer the question of the why, but it is not the whole ball game.

Another conception of a political boycott is one in which "the boycotters should be attempting to influence government action."189 The identity of the boycott target can also help illuminate whether a boycott is political, but again, does not wholly answer the question. While recognizing the utility of the boycott target as evidence in assessing its political versus economic nature, allowing only boycotts directly aimed at the government to escape antitrust liability misses a huge swath of political boycotts-misses even those in Claiborne Hardware.

A government-focused conception of the boycott misses the reality that many of the most important social and political actors are not in the government. People's lives are affected by more than merely who holds office. Consider some of the examples discussed in Part II.A, even in the instances where the government was not the target, there is little ground to stand upon to claim that these boycotts were not political. For example, the Cracker Barrel boycott dealt only with the company at hand; the boycotters were not even trying to influence the corporation to behave in the

${ }^{187}$ Elhauge, supra note 184, at 1197.

${ }^{188} \mathrm{Id}$.

189 Jennifer L. Dauer, Comment, Political Boycotts: Protected by the Political Action Exemption to Antitrust Liability or Illegal Per Se?, 28 U.C. Davis L. Rev. 1273, 1301 (1995). 
classically political sphere. However, they were seeking an expressly political end through their boycott-the change in a discriminatory policy mandating the firing of employees based on sexual orientation. This was clearly not an economic goal; at the same time, the target was clearly not the government. A focus on the identity of the target is useful as evidence to establish the character of the boycott, but it does not definitively answer the question as to whether a given boycott is economic or political. The analysis must instead be aimed at the ultimate ends of the boycotters. In an economic boycott, the ultimate end is to impact the market position of the boycott target. And while a political boycott very well may have the ancillary effect of altering such market position, the ultimate end is to alter social or political reality.

\section{B. Labor Boycotts}

The field of labor law is one occupied by an overarching federal regulatory regime; on these grounds, this Article does not include labor boycotts in its analysis. The labor movement serves as the historical backdrop for many people's conceptions of boycotts and picketing, and much of this is viewed as part of a contentious history, with boycotts in the nineteenth century seen as wholly illegal, considering "[t]he bare assertion of such a right [as] startling." ${ }^{190}$ However, with the passage of the National Labor Relations Act in 1935, ${ }^{191}$ the federal government established a set of rules governing conflicts between labor and management. The federal statutory framework has filled the field of labor regulation, ${ }^{192}$ leaving certain practices - for example, picketing one's own employer ${ }^{193}$ —in play, and others - the secondary boycott ${ }^{194}$ — out of bounds. With this field regulated as it is, the First Amendment analysis in the courts has been different for labor boycotts, and thus they are left aside for our purposes.

While the argument has been made that Claiborne Hardware should not be read as sanctioning political boycotts in general ${ }^{195}$ because of the decision of the same term, International Longshoreman's Assn. v. Allied

\footnotetext{
190 State v. Glidden, 8 A. 890, 894 (Conn. 1887). For a more complete discussion of the labor boycott in America, and the way in which it was seen as illegal, see MiNDA, supra note 7 , at 33 et seq.

191 National Labor Relations Act, 29 U.S.C. §§ 151-169.

192 See Int'l Ass'n of Machinists \& Aerospace Workers v. Wis. Emp't Relations Comm'n, 427 U.S. 132, 140-48 (1976); San Diego Bldg. Trades Council v. Garmon, 359 U.S. 236, 244-45 (1959).

19329 U.S.C. $\S 157$.

19429 U.S.C. $\S 158(b)(4)(B)$.

195 Gordon M. Orloff, Note, The Political Boycott: An Unprivileged Form of Expression, 1983 DUKE L.J. 1076, 1090-91.
} 
International Inc., ${ }^{196}$ this point wholly misses the doctrinal differences when operating within the highly-structured field of labor law. Keeping in mind the different situation of labor because of the federal statutory scheme, there rests no inconsistency between the cases. Allied itself recognized that since a labor boycott was at issue, the case was operating within an already existing framework reflecting "a careful balancing of interests," was not for the Court to create an exception to the carefully balanced legislation. Analysis under the NLRA will necessarily be different than that conducted outside of it. There is a well-recognized prohibition against secondary labor boycotts, created by the political branches, and Allied simply recognizes this fact. ${ }^{198}$ The Court in Allied stressed that it was objectionable for a labor union to "marshal against neutral parties the considerable powers derived by its locals and itself under the federal labor laws." 199

An examination of the motivation of the dockworkers in Allied highlights some of the difficulty in distinguishing the political boycotts so far discussed here from labor boycotts. This union undertook their boycott in order to "to protest the Russian invasion of Afghanistan." 200 This appears to be just the sort of political or social end that should be at the heart of First Amendment protection. Distinguishing these types of labor boycotts, as opposed to labor boycotts undertaken to increase wages or gain some material benefit to the strikers, ${ }^{201}$ from political boycotts is an extremely difficult task. As the Court has been unwilling to consider the motivations of union boycotters and instead makes the distinction based on boycotter identity in this context, in terms of litigation, labor boycotts exist in a different space than political consumer boycotts.

\section{Difference Between Individual Economic Retaliation and Boycotts}

Another continuing concern that becomes entangled with the boycott is that of direct, one-on-one economic retaliation. Though boycott opponents are quick to conflate the two, listing each as examples of the same phenomenon, it is critical to distinguish between them. In NAACP $v$.

196456 U.S. 212 (1982).

${ }^{197}$ Id. at 227-28 (citing NLRB v. Retail Store Employees, 447 U.S. 607, 617 (1980) (Blackmun, J., concurring)).

198 “The secondary boycott provisions in $\S 8(\mathrm{~b})(4)(\mathrm{B})$ [of the NLRA] prohibit a union from inducing employees to refuse to handle goods with the object of forcing any person to cease doing business with any other person.” Allied Int'l, 456 U.S. at 222.

${ }^{199}$ Id. at 225.

${ }^{200} \mathrm{Id}$. at 214.

201 Such labor boycotts appear closer in kind to economic boycotts than to the political boycotts that are at the heart of the analysis in this Article. 
Alabama ex rel. Patterson and in Brown v. Socialist Workers '74 Campaign Committee, the parties charged that they would be subject to economic retaliation, namely in the form of discontinued employment. Three elements separate political boycotts from economic retaliation. A firing based on someone's political preferences or actions contains none of the persuasive elements of a boycott, it is merely punitive. A boycott is discursive, with the participants hoping to persuade the target to political or social action. They are saying something to advocate for their political ends. A political firing, on the other hand, has no discursive element. It has one-way impact. Furthermore, a political boycott can, and does, come to an end, while a firing ends the relation entirely. It is possible, though not probable, that individuals may be re-hired, but this does not change the finality of a firing. The Cracker Barrel example discussed in Part II.A illustrates the difference between these two phenomena. The employees were fired because of who they were, this was not an act within the bounds of First Amendment protection, though was also not outside of the law because the prevention of discrimination based on sexual orientation is still not part of the law ${ }^{202}$ and was certainly not in 1991 Tennessee. The subsequent boycott was well within the core of the First Amendment, a political boycott aimed at changing social decisionmaking. ${ }^{203}$ The differences inherent in the Cracker Barrel example clearly illustrate the way boycotts differ from political firings.

In addition to the discursive differences between boycotts and firings, the related power structures also give rise to an extreme difference between the two. On average, the power differentials between an employer and employee are so great that we do not give constitutional credit to the employer's use of its superior power position to hold political sway over the employee. In a boycott, the one-on-one power differential is structured in the opposite way as in economic retaliation. The individual consumer has negligible power in the relationship with producers. This power-focused analysis does not suggest that once a boycott has gained enough traction to make an impact it loses its protected character. Rather, in much the same way there is no problem with the aggregation of votes causing a change in political reality, the same is true of the aggregation of consumer choice in a boycott. In a firing, the individual with greater economic power is retaliating against the individual with lesser economic power. "[O]wners of

\footnotetext{
${ }^{202}$ See Employment Non-Discrimination Act, H.R. 1397, 112th Cong. (2011); Employment Non-Discrimination Act, S. 811, 112th Cong. (2011). Tennessee's current employment non-discrimination statute only covers "race, creed, color, religion, sex, age or national origin,” TENN. CODE ANN. § 4-21-401, offering no protection based on sexual orientation.

${ }^{203}$ Harper, supra note 29, at 426.
} 
capital have specialized and very unequal market power," and thus already have "disproportionate leverage over important social decisions."204 This unequal power structure imbues the employer with power over the employee, a relation that does not exist between consumer and producer.

A third important difference between boycotts and economic retaliation rises out of this same power structure. Firings are unilateral. One individual makes one decision and carries it out. Boycotts are just the opposite. Operating alone, one individual consumer boycotting has no impact. Boycotts must enlist others, persuade others to action on the strength of the idea or the cause being advocated. Furthermore, boycotts demand constant decisions by a large number of people across a long period of time. In this way, boycotts demand constant thought and reevaluation in a way that a firing simply does not. A firing requires one decision at one point in time, while a boycott requires countless decisions spread out over time. Because of the continuing need for a large number of decisions in a boycott, they are also in a way incremental - the strength and, thus, utility of a boycott can fluctuate across time. People can initially be convinced of a boycott's goals, only to change their mind and cease boycotting. Boycotts are also incremental because there are always numbers, often large numbers, of people who are not convinced or simply are not engaged so do not participate in the boycott. In this way, the producer still has funds coming in, albeit perhaps less than before the boycott, in a way that a fired employee does not. This incremental nature of the boycott sets it apart from political firing where the decision is final and all encompassing. While there may be scenarios where a boycott might operate more like mere retaliation, acknowledging this possibility is not enough to delegitimize boycotts generally. The difference discussed here between economic retaliation and a boycott offers a way to address the more difficult questions of administrability.

\section{Concern Over “Less Legitimate” Boycotts}

Boycotts have the ability to exact real human costs from those targeted. A debate rages around their use and they are deployed in litigation precisely because boycotted business can, in fact, be deeply impacted with effects that may ripple out to owners, employees, and even the community in which a boycotted business resides. With these human tolls in mind, another boundary which some may think calls for policing are boycotts deployed because of who someone is, rather than for a decisional goal. ${ }^{205}$

\footnotetext{
${ }^{204}$ Id. at $426-27$.

${ }^{205}$ Id. at $429-30$.
} 
An example is admonitions to "buy white" in the Jim Crow South. ${ }^{206}$

Recognizing these difficulties, however, does not mean condemning the boycott. While no one would laud boycotts deployed based solely on identity nor revel in economic suffering, the First Amendment benefitsboth in terms of allowing consumers to use their main resource in the economic sphere to impact the political as well as the deep interest of the electorate in disclosure-outweigh these real concerns.

The First Amendment is a rough and tumble place. Outside of the scope of accepted anti-discrimination laws, there is little ground to stand upon to hold identity-based boycotts outside the law. The answer to any boycott one finds abhorrent is to marshal support for the target or undermine the boycott through further speech in the marketplace. ${ }^{207}$ There are countless examples of groups with what would most often be considered objectionable ideas or beliefs finding protection within the First Amendment. $^{208}$ The First Amendment does not only protect that speech which most people find praise-worthy. To paraphrase the old adage: I may disapprove of why you boycott, but I will defend to the death your right to boycott. $^{209}$

Michael Harper has attempted to draw a principled line for distinguishing between boycotts, but his distinction may not hold up. He charges that conceiving of the political boycott as a "right to attempt to affect social decisionmaking readily distinguishes legitimate boycotts from those that refuse to patronize a business because of the identity of its owners or managers."210 He argues that if someone refuses to patronize because of

206 See, e.g., NAACP v. Alabama ex rel. Patterson, 357 U.S. 449, 462 (1958). In the Brief for the Petitioner in this case, they cite an instance of a state Senator telling people to "think white, talk white, buy and hire white." Pet. Br. 13 n.7.

207 See, e.g., Adam Gabbatt, J.C. Penney Reveals Customers' Show of Support for Ellen DeGeneres, THE GUARDIAN, Feb. 9, 2012 (customers voicing support for spokeswoman in response to pressure and threats of boycott from another group over her sexual orientation).

${ }^{208}$ See, e.g., Snyder v. Phelps, 131 S. Ct. 1207 (2011) (First Amendment protection for picketers at a military funeral holding signs including “Thank God for Dead Soldiers,” "God Hates Fags," and "You're Going to Hell,” among others); Virginia v. Black, 538 U.S. 343 (2003) (holding a statute banning cross burning facially unconstitutional under the First Amendment); Hustler Magazine v. Falwell, 485 U.S. 46 (1988) (First Amendment protection for magazine describing preacher's "first time" as "during a drunken incestuous rendezvous with his mother in an outhouse"); Nat'l Socialist Party of Am. v. Vill. of Skokie, 432 U.S. 43 (1977) (reversing state injunction preventing Neo-Nazis from marching with swastikas through mainly Jewish community, home to Holocaust survivors); Robb v. Hungerbeeler, 370 F.3d 735 (8th Cir. 2004) (determining denial of highway adoption by the Ku Klux Klan was unconstitutional).

${ }^{209}$ Evelyn BeAtrice Hall, The Friends OF Voltaire 199 (1906) ("I disapprove of what you say, but will defend to the death your right to say it.”).

${ }^{210}$ Harper, supra note 29, at 429. 
an immutable characteristic of the target's identity this should not be classified as a political boycott because it does not have political ends, even if the boycott cannot be classified as economic in the sense that the altered competition economically benefits the boycotters. A political boycott wants to achieve something; it is an impetus to persuade the target to action in the political or social sphere. Boycotting based upon identity rather than activity need not be sanctioned because with identity, there is no decisionmaking to be targeted via the persuasive mechanisms of the boycott. $^{211}$

While initially very appealing, this argument fails to sufficiently consider that making such a distinction is extremely difficult, if not impossible. In fact, the distinction Harper seeks to draw between identity and action is one already repudiated by the Court in another context. In Buckley, the Court rejected line drawing between contributors and members. ${ }^{212}$ For many, the actions they take are intimately tied to their identities and trying to pull the two apart is a futile effort. Attempting to pull apart identification and activity is often a losing battle. ${ }^{213}$ Because boycotts only have their impact and exact costs when joined by many people, the best and most effective answer to boycotts deployed for objectionable reasons is "more speech." 214

\section{CONCLUSION}

The political boycott falls within the core of First Amendment protection as speech that "has always rested on the highest rung of the hierarchy of First Amendment values."215 Despite the long and storied history of the political boycott in the United States, there is a current trend in litigation, where the deployment of boycotts is enumerated among the reasons why a group should qualify for an as-applied exemption to established compelled disclosure laws. ${ }^{216}$ While some other actions these

${ }^{211}$ Id. at 429-30.

212 Buckley v. Valeo, 424 U.S. 1, 66 (1976).

213 See, e.g., Christian Legal Soc'y v. Martinez, 130 S. Ct. 2971, 2990 (2010) (declining "to distinguish between 'status and conduct”"); see also Lawrence v. Texas, 539 U.S. 558, 575 (2003)(same).

214 Brown v. Hartlage, 456 U.S. 45, 61 (1982) (quoting Whitney v. California, 274 U.S. 357, 374 (1927) (Brandeis, J., concurring)).

215 NAACP v. Claiborne Hardware, Co., 458 U.S. 886, 913 (1982) (quoting Carey v. Brown, 447 U.S. 455, 467 (1980)).

${ }^{216}$ See, e.g., Protectmarriage.com v. Bowen, 599 F. Supp. 2d 1197, 1201 (E.D. Cal. 2009) (quoting Declaration of John Doe \#1) ("His business has since been targeted by numerous boycotts, several orchestrated through Facebook. At one point, someone paid for a sponsored link on Google so that a search for John Doe \#1's store resulted in a website referencing his support for Proposition 8 and urging a boycott.”); Doe v. Reed, No. 09-559, 
litigants have experienced should be considered in the harassment analysis when the courts weigh the balance between the probability of harassment and the state's interests in preventing fraud or in providing the electorate with information, any recourse to the boycott to build a record of harassment is inappropriate. It should not even be listed among the examples presented to a court. Especially in this realm where the Court has recognized a lesser evidentiary burden, ${ }^{217}$ the listing of non-harassment actions - such as the boycott—amongst arguable examples of harassment clouds the issue, inappropriately placing the burden on the court to cull through the many non-examples that muddy the evidentiary showing. ${ }^{218}$

If political boycotts were to be considered harassment it would place boycotters in an untenable situation. The state and all the members of the electorate continue to have an abiding interest in the information presented through the compelled disclosure regime, but the actions-actions within the core protection of the First Amendment-of a much smaller subset than the entire electorate would prevent the electorate's access to that information. To punish the entire electorate and the state for the legal and constitutionally cognizable actions of a subset thereof would stand the protections of the First Amendment on their head. Where a political boycott is deployed, the targets would be unable to obtain damages from those actually boycotting in deference to this critical First Amendment right, but under the formulation opponents of compelled disclosure would advocate, targets could instead deprive the entire electorate of recognized important information. If this Article has shown nothing else, it has established the political boycott as a form of expression having the law's highest protection. Though individuals may not like being boycotted, that is not a high enough standard for a boycott to suddenly be transformed from "an inherent right of the American people" ${ }^{219}$ into harassment. The courts must not "condemn those who have legally exercised their own constitutional rights in order to display their dissatisfaction."220 Turning the legal rights of others into harassment in the name of the First Amendment

Pet. Br. 11 ("Boycotts were threatened: 'We shall boycott the businesses of EVERYONE who signs your odious, bigoted petition.'”); Citizens United v. Fed. Election Comm’n, 130 S. Ct. 876, 981 (2010) (Thomas, J., concurring in part, dissenting in part) ("opponents threatened to boycott and picket the next festival”).

${ }^{217}$ Buckley, 424 U.S. at 74.

${ }^{218}$ See, e.g., Brief for Lambda Legal Defense and Education Fund., Inc. et al. as Amici Curiae Supporting Respondents, Doe v. Reed, 130 S. Ct. 2811 (2010) (No. 09-559) ("While their list contains a handful of allegations of improper conduct, it is inflated by countless incidents in which opponents of lesbian and gay rights simply felt discomfort at being faced with vigorous but constitutionally protected expressions of disagreement.”).

${ }^{219}$ Bowen, 599 F. Supp. 2d at 1218.

${ }^{220} \mathrm{Id}$. 
does a great disservice to the very Amendment those targeted by boycotts are looking in which to take refuge. "There are laws against threats and intimidation; and harsh criticism, short of unlawful action, is a price our people have traditionally been willing to pay for self-governance. Requiring people to stand up in public for their political acts fosters civic courage, without which democracy is doomed."221

${ }^{221}$ Doe v. Reed, 130 S. Ct. 2811, 2837 (2010) (Scalia, J., concurring). 